\title{
Transition heuristic frameworks in research on agro-food sustainability transitions
}

\author{
Hamid El Bilali ${ }^{1}$ (iD
}

Received: 31 July 2018 / Accepted: 31 October 2018 / Published online: 8 November 2018

(C) The Author(s) 2018

\begin{abstract}
The agro-food system needs a genuine sustainability transition to achieve sustainable food and nutrition security in the face of climate change, population growth, ecosystem degradation and increasing resource scarcity. Agro-food sustainability transitions refer to transformation processes needed to move towards sustainable agriculture and food systems. There is a broad range of theoretical and conceptual frameworks that have been used to understand and promote transition towards sustainability. These include the multi-level perspective (MLP) on socio-technical transitions, transition management (TM), strategic niche management (SNM), technological innovation system (TIS) and social practice approach (SPA). The paper analyses the use of these heuristic frameworks in research on agro-food sustainability transitions. A search carried out in March 2018 on Scopus yielded 791 documents, and 127 research articles underwent a systematic review. Results show that more than three-fifths of research papers dealing with sustainability transitions in agriculture, food processing, distribution and consumption use at least one of the five heuristic frameworks (MLP, TM, SNM, TIS and SPA). The MLP is the most prominent framework in research on agro-food sustainability transitions, followed by TM, SPA, SNM and then TIS. Nevertheless, MLP is increasingly complemented with frameworks that focus on humanrelated and social factors (SPA), management and governance (TM, SNM) or agency and interactions between actors (TIS) in sustainability transitions processes. Therefore, the paper makes the case for more integration of transition frameworks in order to better nurture and foster transitions towards sustainable agro-food systems.
\end{abstract}

Keywords Sustainability transitions $\cdot$ Agriculture $\cdot$ Food $\cdot$ Multi-level perspective $\cdot$ Transition management $\cdot$ Strategic niche management $\cdot$ Social practice theory $\cdot$ Technological innovation systems

Hamid El Bilali

hamid.elbilali@boku.ac.at

1 Centre for Development Research, University of Natural Resources and Life Sciences (BOKU), Peter Jordan Strasse 76, 1190 Vienna, Austria 


\section{Introduction}

Contemporary environmental problems (e.g. climate change, resource depletion, biodiversity loss) present formidable societal challenges that can be addressed only by radical, structural changes (Elzen et al. 2004; Foxon 2008; Grin 2010). These grand challenges relate to unsustainable consumption and production patterns in systems such as energy and agro-food (STRN 2017). Therefore, transition studies have received increasing attention in both the academic literature (Markard et al. 2012; Lachman 2013; Falcone 2014; Loorbach et al. 2017) and policy arena (European Environment Agency 2016, 2018; OECD 2011; UNEP 2011). The field has diversified in terms of journals and grown in terms of the numbers of publications (STRN 2017). A great strength of transitions research is that it addresses systemic changes (Sustainability Transitions Research Network 2010). The notion of "sustainability transition" refers to transition towards sustainable systems (Geels 2018; Lachman 2013). Grin et al. (2010) considered sustainability transition as a "radical transformation towards a sustainable society in response to a number of persistent problems confronting contemporary modern societies". Markard et al. (2012) defined sustainability transitions as "long-term, multi-dimensional and fundamental transformation processes through which established socio-technical systems shift to more sustainable modes of production and consumption" (p. 956).

The Sustainability Transitions Research Network (STRN 2017) argues that sustainability transition is a broad and interdisciplinary research field. In fact, sustainability transitions have several features that make them a special topic in sustainability scholarship: multi-dimensionality and co-evolution (transitions are co-evolutionary processes, involving changes in different dimensions of socio-technical systems); multi-actor process (transitions are enacted by a range of stakeholders/actors); stability and change (dialectic relationship between stability and change is central in sustainability transition research); long-term process (transitions may take decades to unfold); open-endedness and uncertainty (sustainability journeys are open-ended as there are multiple transition pathways, which implies uncertainty); values, contestation, disagreement (sustainability notion is highly contested, so different actors tend to disagree about sustainability transitions pathways); public policy (public policy plays a central role in shaping transitions towards sustainability).

Since the publication by the Sustainability Transitions Research Network (STRN) of its first research agenda in July 2010 (Sustainability Transitions Research Network 2010), sustainability transition scholarship has deepened intellectually, broadened empirically and extended geographically. Nevertheless, sustainability transitions research field tended to overlooked agro-food systems. In fact, work on sustainability transitions tended to focus on energy and mobility systems (Hinrichs 2014; Markard et al. 2012; Sustainability Transitions Research Network 2018; Truffer and Markard 2017). Nevertheless, the agro-food system - which lies at the centre of a global nexus of environmental, social and economic problems - is in need of a genuine sustainability transition as humanity faces the grand challenge of achieving sustainable food security in the face of climate change, population growth, ecosystem degradation and increasing resource scarcity (El Bilali et al. 2018; Freibauer et al. 2011; Garnett 2014; Garnett et al. 2013; Gladek et al. 2016; Godfray et al. 2010b; IPES-Food 2015; Lang 2009; Searchinger et al. 2013; WWW-UK 2013). Furthermore, environmental, social and economic challenges facing the agro-food system are interconnected and magnify one another (Hinrichs 2014). This is exacerbated by an unprecedented confluence of pressures on modern agro-food systems (e.g. poverty, land degradation, hunger and malnutrition, inadequate diets, water scarcity, social inequalities, 
biodiversity loss, climate change) (FAO 2014). Moreover, modern agro-food systems failed to address the issues of food insecurity and malnutrition (Foresight 2011; Godfray et al. 2010a, b; WWW-UK 2013).

There is a broad range of theoretical and conceptual frameworks that have been used to conceptualise, understand and promote transition towards sustainability (Falcone 2014; Geels 2005a; Grin et al. 2010; Lachman 2013; Markard et al. 2012; Sovacool and Hess 2017; STRN 2017). For instance, Sovacool and Hess (2017) identified 96 theories and conceptual approaches spanning 22 identified disciplines that are useful at explaining sociotechnical changes; among these, fourteen theories ${ }^{1}$ were deemed most useful and relevant, e.g. socio-technical transitions, social practice theory, actor-network theory (Callon 1999; Latour 2013; Paredis 2011). Lachman (2013) provided a review of the more notable transition frameworks: the multi-level perspective (e.g. Geels 2002, 2011), strategic niche management (e.g. Raven and Geels 2010; Schot and Geels 2008), transition management (e.g. Loorbach and Rotmans 2006; Loorbach et al. 2008; Loorbach 2010), technological innovation systems (e.g. Bergek et al. 2008; Hekkert et al. 2007), Techno-Economic Paradigm (TEP) shifts (e.g. Freeman and Perez 1988; Van den Bergh and Oosterhuis 2008; Geels 2011) and Socio-Metabolic Transitions (e.g. Fischer-Kowalski and Rotmans 2009; Sieferle 2010; Fischer-Kowalski 2011). Likewise, Falcone (2014) carried out a survey of the main transition frameworks, namely the multi-level perspective (Geels 2002; Geels and Schot 2007; Smith et al. 2010), strategic niche management (Kemp et al. 1998; Smith 2007; Raven and Geels 2010), transition managementent (Loorbach 2010; Kern 2012) and technological innovation systems (Bergek et al. 2008; Hekkert et al. 2007). According to Hinrichs (2014), there are two main orientations in transitions research and scientific approaches: the MLP on transitions, which investigates pathways of sustainability innovation, and Social Practices Approach (SPA), which considers how people's ordinary practices and routines can present openings for more sustainable shifts. Sustainability transition frameworks differ in terms of epistemological styles, ontological assumptions or methodological commitments (Geels 2011).

There was until recently a lack of research on agro-food systems in sustainability transitions scholarship, but it is now rapidly emerging. Moreover, there is so far no comprehensive analysis of the use in - and consequently suitability to-agro-food systems of heuristics proposed to study transitions in energy and mobility systems. To address these gaps in the present literature, this paper provides a critical, systematic overview on the use of five prominent heuristic frameworks (multi-level perspective, strategic niche management, transition managementent, technological innovation systems, social practices approach) in research on agro-food sustainability transitions. The paper also helps in demonstrating the specificity of agro-food transitions research, thus enriching the sustainability transitions research field.

\footnotetext{
1 These are: sociotechnical transitions, social practice theory, Discourse Theory, Domestication Theory, Large Technical Systems, Social Construction of Technology, Sociotechnical Imaginaries, actor-network theory, Social Justice Theory, Sociology of Expectations, Sustainable Development, Values Beliefs Norms Theory, Lifestyle Theory, and the Unified Theory of Acceptance and Use of Technology (Sovacool and Hess 2017: 703).
} 


\section{Transition frameworks: an overview}

Innovation system (IS) theory suggests that innovation occurs in the context of an entire system and not only through entrepreneurs (Twomey and Gaziulusoy 2014; Weber and Truffer 2017). It accounts for change beyond technical and economic spheres (Hekkert et al. 2007; Lachman 2013; Sartorius 2006). A Technological Innovation System (TIS) is defined as "a dynamic network of agents interacting in a specific economic/industrial area under a particular institutional infrastructure and involved in the generation, diffusion and utilisation of a technology" (Carlsson and Stankiewicz 1991). The main purpose of the TIS approach is to consider all the activities that contribute to the development, diffusion and use of innovations as system functions. In the TIS approach, the development of a new technology results from the positive fulfilment of seven functions: entrepreneurial activities, knowledge development, knowledge diffusion, search guidance, market formation, resource mobilisation, and advocacy and legitimacy creation (Bergek et al. 2008; Hekkert et al. 2007). More recently, Markard (2018) introduced a TIS life-cycle framework that distinguishes between four stages of development, i.e. formation, growth, maturity and decline. The major contribution of IS perspectives was to introduce a systemic perspective (e.g. a focus on weak networks, institutional failures, infrastructure failures) replacing narrow market concepts (Jacobsson and Bergek 2011).

The multi-level perspective (Rip and Kemp 1998; Geels 2002, 2005a, b, 2010, 2011; Smith et al. 2005, 2010; Schot and Geels 2008) posits that transitions come about through interaction processes within and between three analytical levels: niches (micro level; locus of radical innovations); socio-technical regimes (meso-level; locus of established practices and associated formal, normative and cognitive rules); and an exogenous socio-technical landscape (macro level). Niches are spaces (e.g. research and development laboratories, small market niches, demonstration projects) where innovative activity takes place and where protection is offered against dominant rules (Smith et al. 2010; Geels 2011). The socio-technical regime comprises the network of actors and social groups, the formal and informal rules they maintain to run a dominant socio-technical system, and related material and technical elements (Geels 2011). Regimes tend to change only incrementally and rarely undergo transformation or reconfiguration (Lachman 2013). The overarching level, and backdrop to the regime and niche levels, is the socio-technical landscape. It cannot be changed easily and in the short run (Geels 2002; Geels and Schot 2007; Rip and Kemp 1998) and includes trends and global events such as demographic trends, macroeconomic trends, political ideologies and developments, deep societal and cultural values, and climate change (Lachman 2013). Landscape changes can constitute a source of pressures for regime change and/or generate opportunities for niches (Smith et al. 2010). In MLP, transitions are defined as shifts from one regime to another and they result from the interaction between processes at niche-regime-landscape levels; niche innovations build up internal momentum, changes at the landscape level create destabilising pressure on the regime, and regime destabilisation creates windows of opportunity for radical niche innovations that gather momentum to take centre stage within the system (Geels 2006, 2011; Grin et al. 2010; Markard and Truffer 2008). MLP emphasises that processes at niche, regime and landscape levels should be aligned for a transition to be successful (Geels 2011).

Socio-technical transitions are an umbrella term that includes, besides the MLP, a family of approaches such as and Multi-Phase Model, strategic niche management and transition managementent. Strategic niche management (SNM) and transition managementent (TM) emerged from the aspiration to support radical innovation and system transformation 
(Twomey and Gaziulusoy 2014). SNM aims to bridge the gap between niche development and market exploitation. Therefore, SNM scholars focus on the early adoption of innovations, the processes that determine successful niche development as well as niche-regime interactions. SNM promotes reflexive management of niche experiments and initiatives to create momentum for niches to breakthrough (Schot and Geels 2008). The core idea behind SNM is learning (experiential, social, etc.) (Raven and Geels 2010). Transition management (TM) shares many features with SNM, focusing on the key processes in establishing a niche (e.g. promoting learning based on experiments, developing rules, stabilising networks). It emphasises the importance of creating visions in so-called transition arenas before starting niche experiments (Rotmans et al. 2001; Kemp et al. 2007; Loorbach 2007; Schot and Geels 2008). The TM approach is useful to understand the role of such "transition arenas", where niche players and change-inclined regime actors can form new coalitions (Rotmans and Loorbach 2009). In doing so, TM concentrates on alternative visions to influence the cognitive frames of regime actors (Schot and Geels 2008). It follows a cyclical path consisting of problem structuring and envisioning (strategic level), agenda building and networking (tactical level), experimenting and diffusing (operational level) and evaluating and adjusting (cf. reflexive governance) (Loorbach 2007, 2010; Loorbach et al. 2008).

The Social Practices Approach (SPA) bridges individual lifestyles and socio-technical systems (Hargreaves 2011; Moore 2015). The theory of social practices investigates the social relations between producers and consumers, embedded in infrastructures (Hargreaves et al. 2013; Reckwitz 2002; Shove and Walker 2010; Southerton et al. 2004; Spaargaren and van Vliet 2000; Warde 2005). Shove and Pantzar (2005) and Pantzar and Shove (2010) saw practices as made of skills (knowhow, competence forms), images (meaning, symbols) and materials that are recursively and actively integrated through everyday life. Changing social practices in an innovation process is seen as a collective accomplishment, which questions boundaries around regimes and systems (Pantzar and Shove 2010). Change of social practices, according to Warde (2005), would occur when their continuous replication is disrupted. Regarding change, SPA further distinguishes between practices that are routinely reproduced, and new practices that are more unstable and fluid (Shove and Walker 2010).

\section{Materials and methods}

The paper is based on a systematic review of documents indexed in Scopus database (Table 1). An important step of the process was the selection of the peer-reviewed scientific literature dealing with agro-food sustainability transitions. For that, a literature search was carried out on 3 March 2018, using the Title-Abs-Key search string: (transition AND sustainability) AND (agri* OR agro OR food).

The search on Scopus yielded 791 papers. Further 56 documents were added from the quarterly newsletter of the Sustainability Transitions Research Network (STRN). In order to be included in the systematic review, research articles had to satisfy two requirements, namely to deal with both sustainability transitions and agro-food (agriculture and/or food). In some cases, a scrutiny of full papers was necessary. In fact, 54 records underwent an eligibility check based on full papers. Following screening, scrutiny and eligibility checks, only 127 research articles were included in the systematic review (Table 2). 


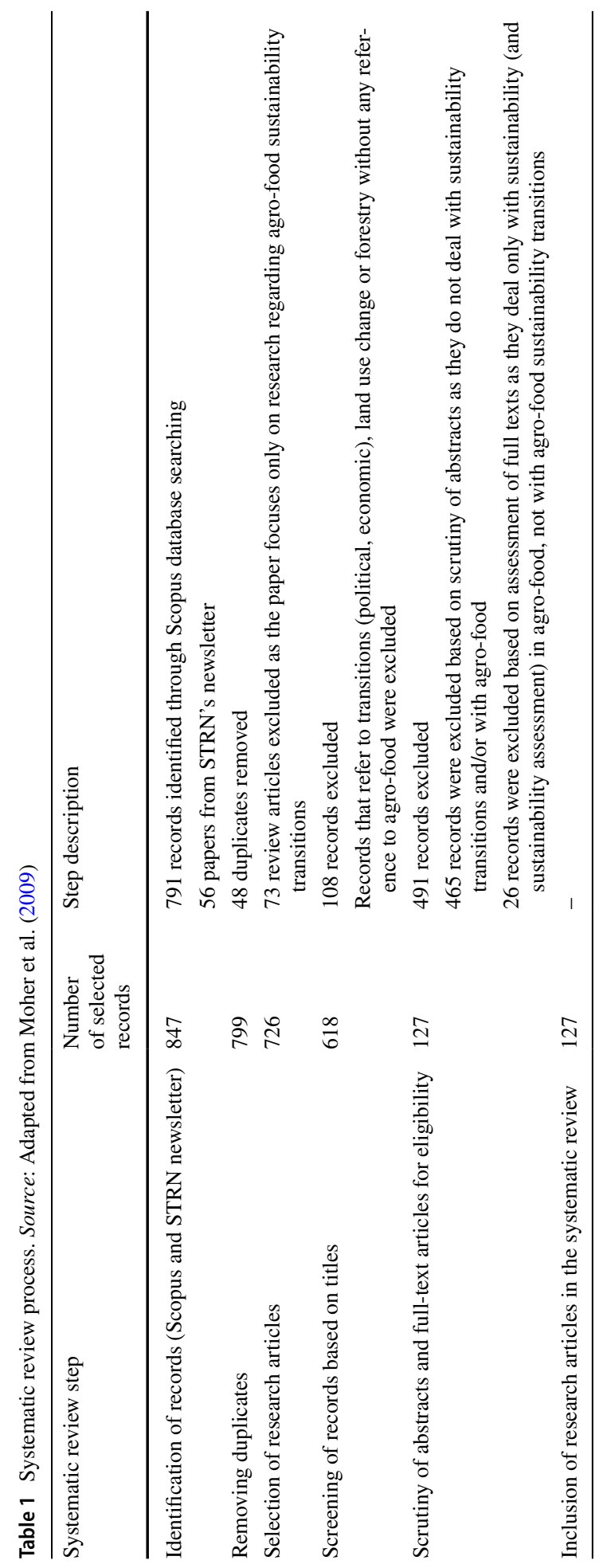




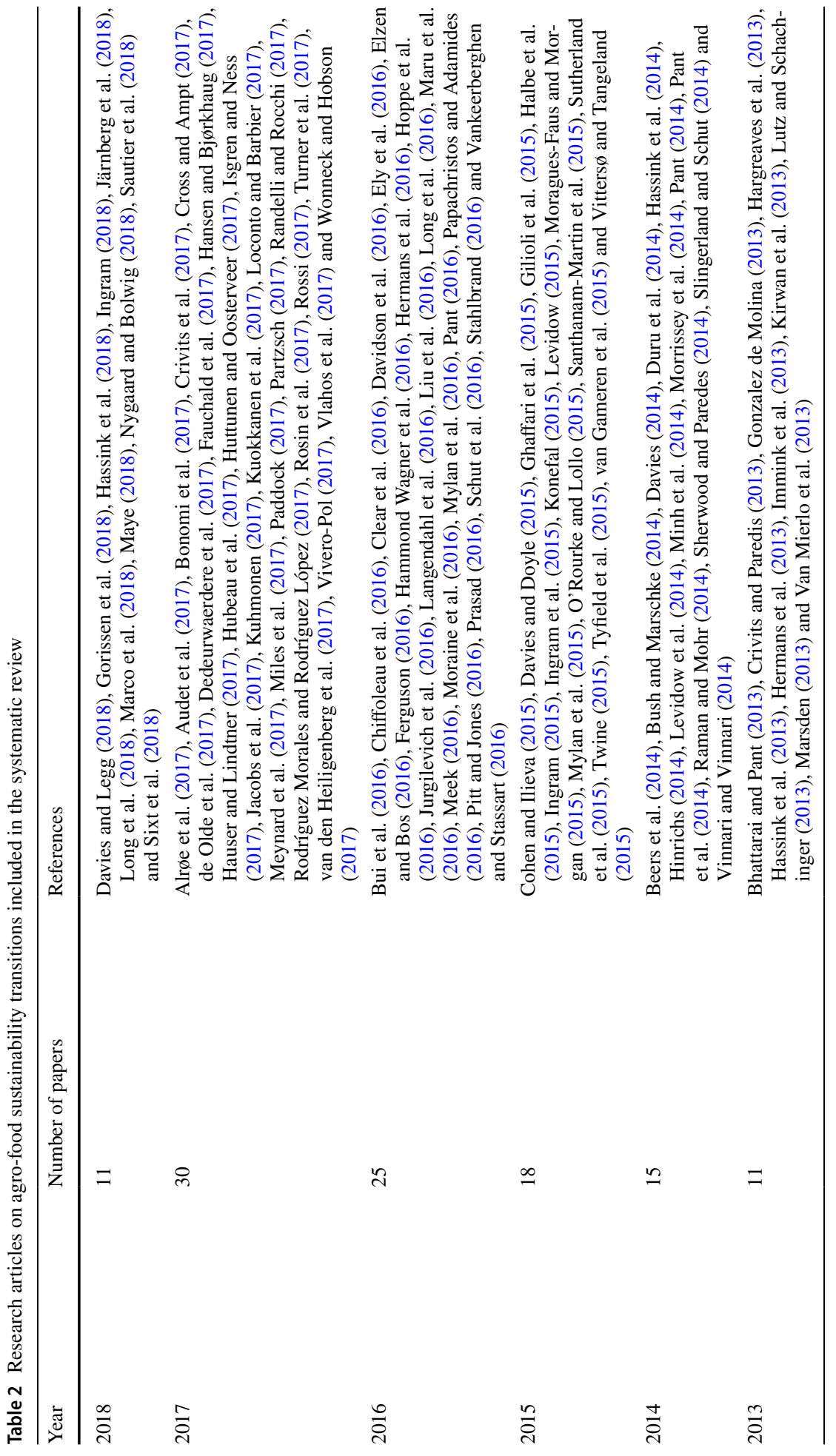




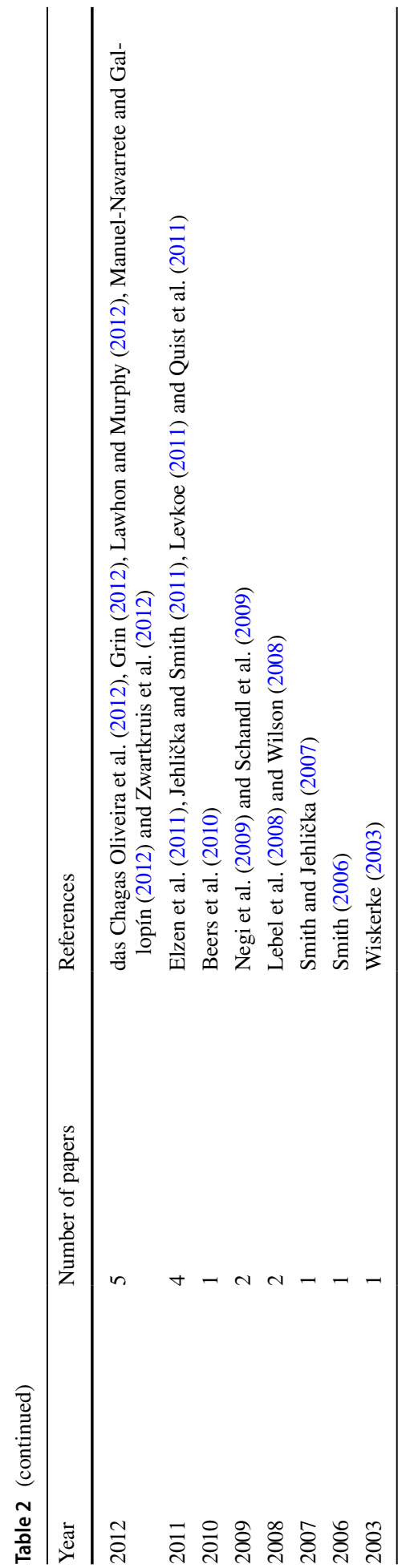

Springer 
Based on the discussion in Sects. 1 and 2, five transition frameworks were selected for empirical analysis: IS/TIS, MLP, TM, SNM and SPA. For each heuristic framework, a search string was elaborated: multi-level perspective (search string: \{multilevel perspective OR \{multilevel perspective OR MLP OR niche), transition management (search query: \{transition management\}), strategic niche management (search query: \{niche management\}), technological innovation systems (search query: \{innovation system \}), social practice approach (search string: \{social practice\} OR "practice theory"). Search was performed on Scopus in the list of 127 selected research articles dealing with agro-food sustainability transitions.

The following topics were addressed for each framework: agriculture sub-sectors (crop production, animal production, fisheries/aquaculture) and stage of the food chain (production, processing, distribution, consumption); niches; interactions with other regimes/sectors (e.g. energy); geography of author affiliations and countries where case studies were performed; main focus of the framework (e.g. niches-regimes interactions, emergence and development of niches, roles of actors in the transition process); weaknesses/critiques to the framework.

\section{Results and discussion}

The results of the systematic review show that all five heuristic frameworks are used in research on agro-food sustainability transitions (Table 3). Moreover, 68.5\% of the selected research papers dealing with agro-food sustainability transitions use at least one transition framework. The multi-level perspective (MLP) is by far the most prominent transition framework followed by transition management (TM), social practice approach (SPA), strategic niche management (SNM) and then innovation systems. It should be pointed out that many papers use different transition frameworks. For instance, Crivits and Paredis (2013) used MLP and SPA, while van den Heiligenberg et al. (2017) integrated insights from the TM literature with innovation systems approach. MLP, TM, SPA, SNM and IS are the dominant transition frameworks, but some authors refer to other approaches such as Socio-Metabolic Transitions (Marco et al. 2018; Schandl et al. 2009).

There are some differences with the use of heuristic frameworks in the mother field of sustainability transitions (Truffer and Markard 2017). In fact, Truffer and Markard (2017) showed that TM is the most prominent transition framework in sustainability transitions field followed by MLP, TIS and then SNM. The authors did not consider SPA in their analysis. This clearly shows that SPA, which focuses on consumption, is mainly used in agro-food research.

The analysis of the trend in the use of transition frameworks in research on agrofood sustainability transitions (Table 4) shows that the use of SPA is rather recent. Meanwhile, SNM was among the first frameworks to be used in research on agro-food sustainability transitions, but it kept marginal in the research field. Likewise, the innovation systems approach is still marginal in the field.

The use of each transition heuristic framework in agro-food sustainability transitions research field is analysed in the following paper subsections. Papers using more than one framework were analysed in a separate subsection (see Sect. 4.6). 


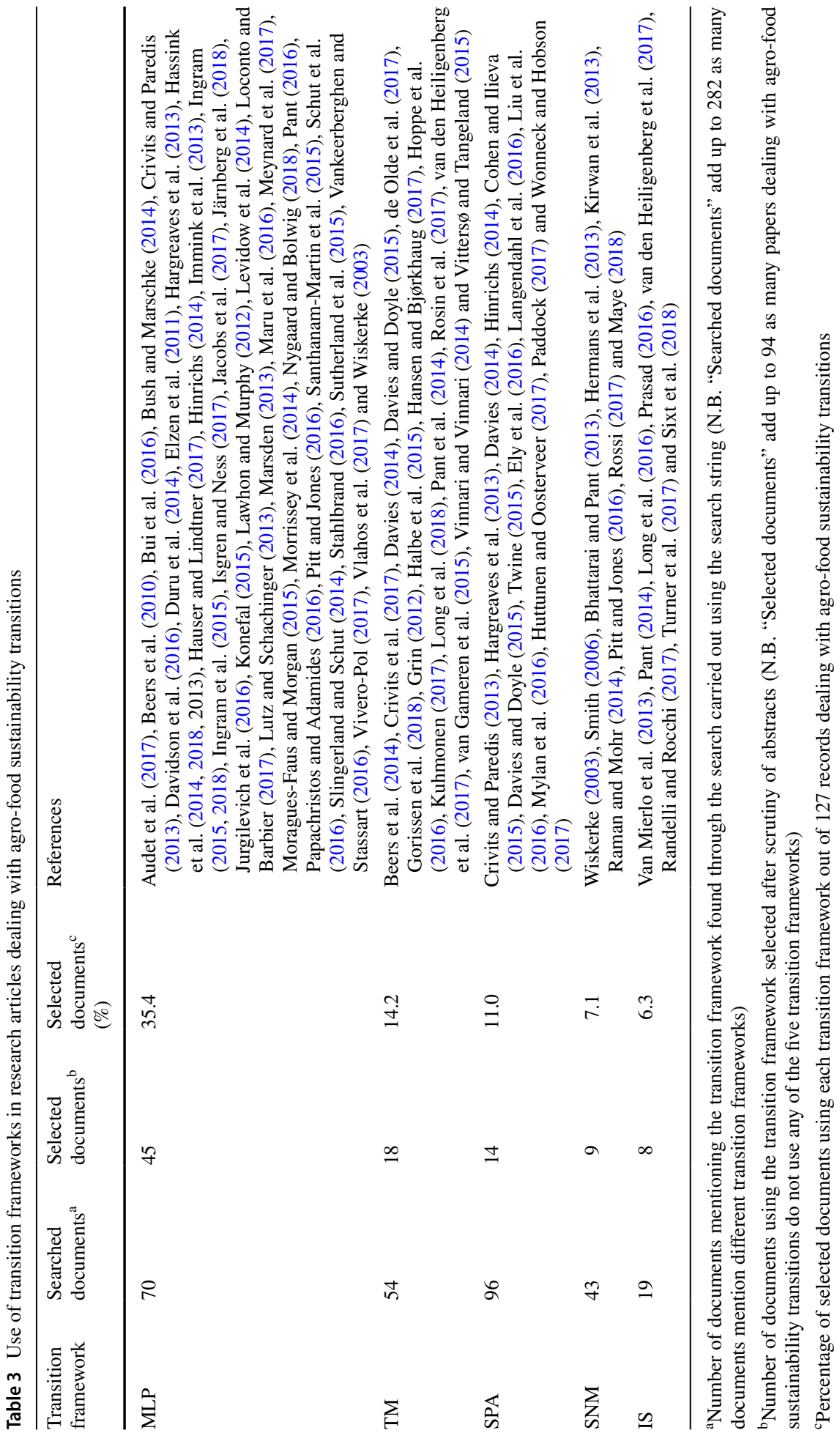


Table 4 Trend in the use of transition frameworks in research on agro-food sustainability transitions

\begin{tabular}{lcllll}
\hline & MLP & TM & SNM & SPA & IS \\
\hline 2003 & & & 1 & & \\
2006 & & & 1 & & \\
2010 & 1 & & 0 & & \\
2011 & 1 & & 0 & & \\
2012 & 1 & 1 & 0 & & \\
2013 & 6 & 0 & 3 & 2 & 1 \\
2014 & 7 & 4 & 1 & 2 & 1 \\
2015 & 6 & 4 & 0 & 3 & 0 \\
2016 & 10 & 1 & 1 & 4 & 2 \\
2017 & 8 & 6 & 1 & 3 & 3 \\
\hline
\end{tabular}

\subsection{Multi-level perspective}

Most of the selected papers focus on crop production; other agriculture sub-sectors such as animal production (Davidson et al. 2016; Elzen et al. 2011; Immink et al. 2013) and fisheries/aquaculture (Bush and Marschke 2014) remain largely underserved. However, some papers address both crop production and animal husbandry. For instance, SanthanamMartin et al. (2015) analysed relation between livestock and natural landscape. As for the stages of the food chain, the main focus is on the production one. Also distribution, sourcing/procurement and catering (Audet et al. 2017; Bui et al. 2016; Stahlbrand 2016) are fairly addressed. Processing stage is underrepresented in research on agro-food sustainability transitions using MLP. In general, MLP is rarely used as a standalone framework to analyse transition in consumption patterns. Some papers adopt a food system approach and address simultaneously different stages of the food chain, such as production and consumption (Jurgilevich et al. 2016; Lutz and Schachinger 2013; Meynard et al. 2017; Morrissey et al. 2014). Other papers deal with different regimes and address the interface between agriculture and energy (Slingerland and Schut 2014; Sutherland et al. 2015; Nygaard and Bolwig 2018) or health care (Hassink et al. 2013, 2014, 2018).

Considering its recognised potential in understanding transitions, many scholars applied MLP to a multitude of cases in the agro-food sector. According to Darnhofer (2015), niches may take the form of "new technologies and practices, new configurations of actor groups, new beliefs and values, new networks, new policies". Niches considered in the selected papers include agro-ecology (Duru et al. 2014; Isgren and Ness 2017; Levidow et al. 2014; Pant 2016), organic agriculture (Hauser and Lindtner 2017), permaculture (Ingram 2018), conservation agriculture (Vankeerberghen and Stassart 2016), integrated farming (Vlahos et al. 2017) and alternative food networks (Audet et al. 2017; Bui et al. 2016; Lutz and Schachinger 2013) (Table 5).

There is a north-south divide in both the affiliations of authors and where case studies on agro-food sustainability transitions are performed. In fact, affiliations are dominated by the UK and the Netherlands. Although also location of case studies on agro-food sustainability transitions is north-biased, distribution is more balanced in this case (Table 5) because, inter alia, northern researchers increasingly perform research also in the Global South (e.g. Ethiopia, Ghana, Mozambique, Uganda).

In MLP, the interactions across niches, regimes and landscapes shape sustainability transitions (Geels 2002, 2011). In general, the focus of papers using MLP is on the 


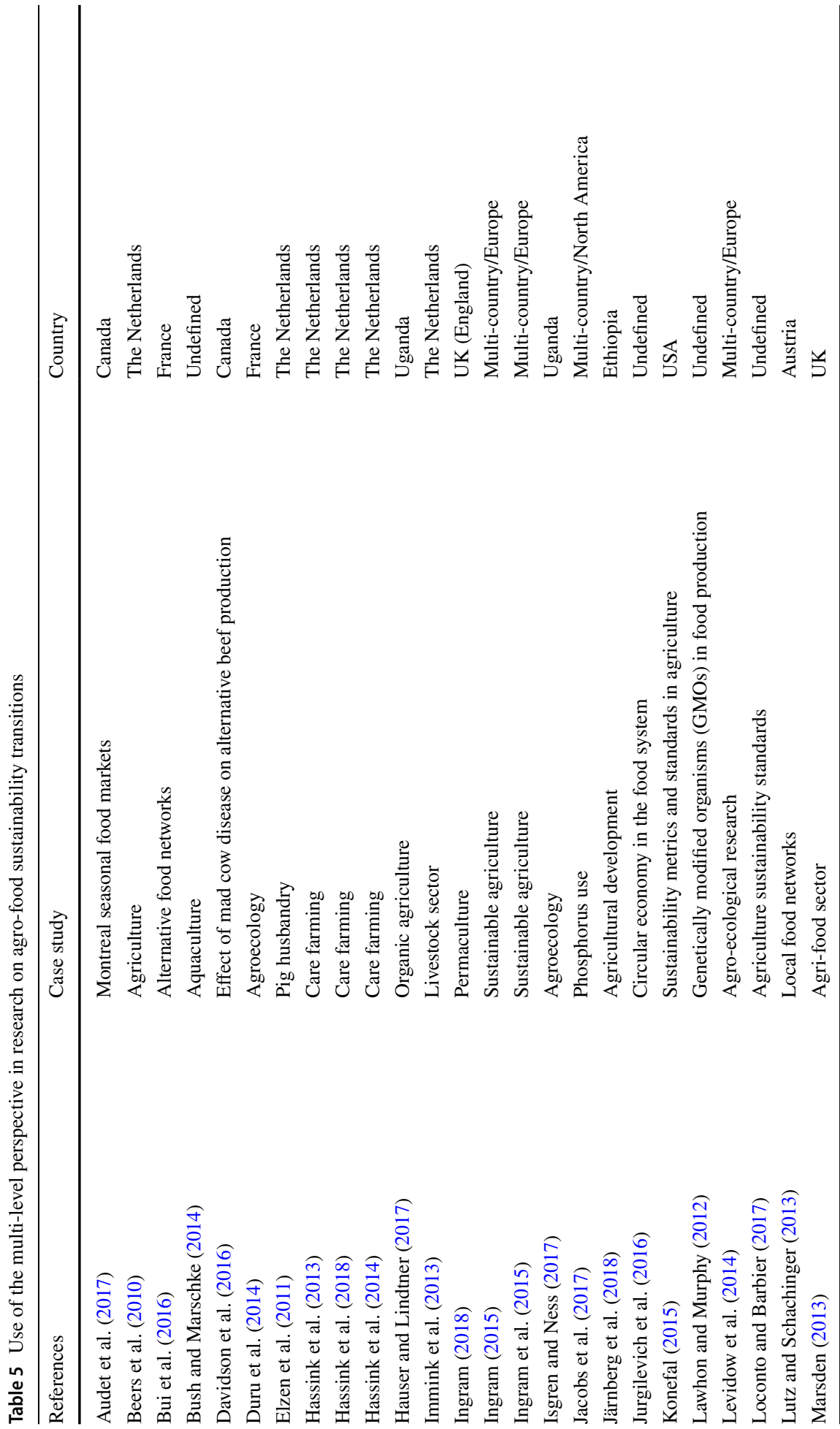




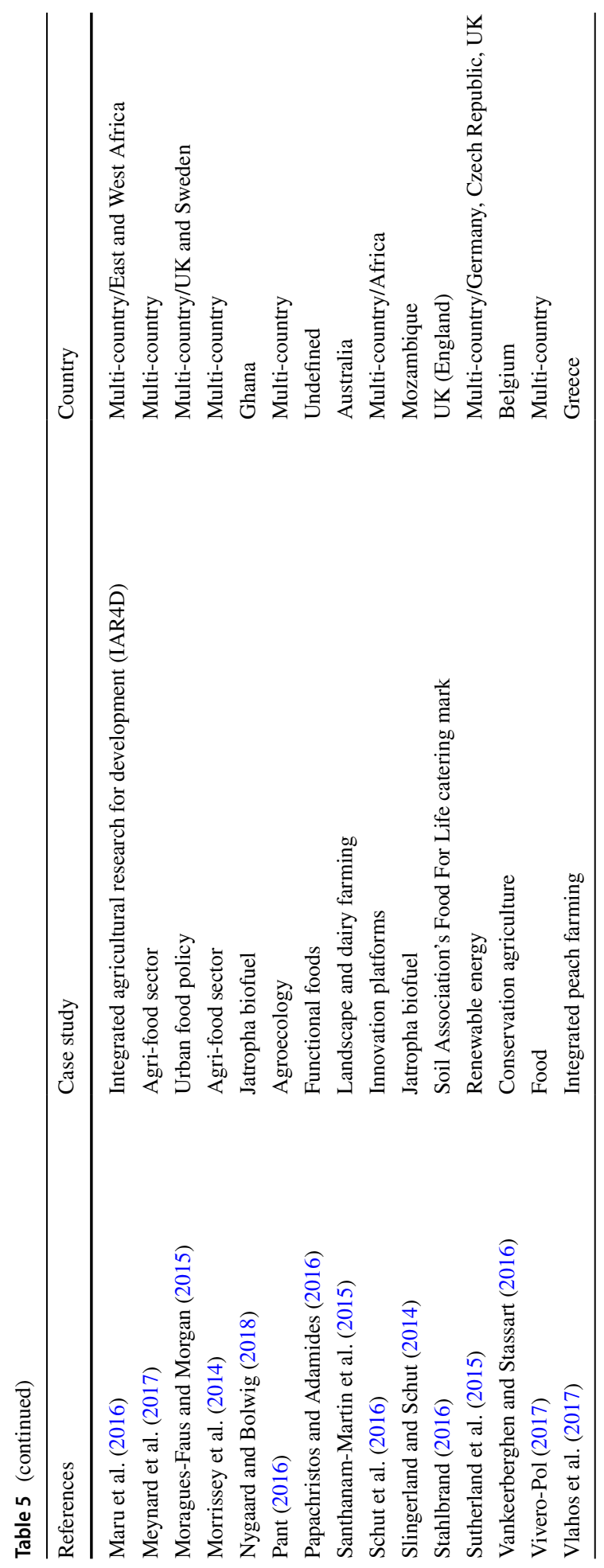


dialectic relations between the emerging niches and established regimes and how their interactions shape transition towards sustainability. In this respect, MLP is similar to the strategic niche management framework. Such papers focus on how niches influence regimes or a component of them, e.g. agricultural knowledge system (Ingram 2018), agricultural research (Levidow et al. 2014; Maru et al. 2016; Schut et al. 2016). Nevertheless, some papers analyse also internal dynamics within niches or regimes as well as transition pathways. For instance, Bui et al. (2016) investigated both niche development trajectories and niche-regime interactions. Isgren and Ness (2017) focused in their analysis on regime dimensions (culture, guiding principles, knowledge, policy, practices/technologies, market relations). Jacobs et al. (2017) drew on MLP to develop transition pathways in North American phosphorus system. Vlahos et al. (2017) pointed out that very often various transition paths unfold simultaneously rather than a single transition pathway.

Although MLP is by far the most prominent transition framework also in agro-food sustainability transitions research field, some scholars highlight its inadequacy for understanding and nurturing agro-food sustainability transitions in some specific contexts. For instance, Audet et al. (2017) pointed out that while MLP anticipates that sustainability transition would depend on the protection of niches that face the agro-food regime, the Montreal seasonal food markets do not fit in this portrait as they evolve at the intersection of the regime and niches. Bui et al. (2016) highlighted that MLP does not allow elucidating the mechanisms of niches contribution to regime reconfiguration. According to Hassink et al. (2018), "several aspects need more attention like agency, interactions across system boundaries and multi-regime interactions" (p. 186). Transition in MLP is considered as a regime change, but Ingram et al. (2015) pointed out that "the transition to sustainable agriculture might be understood as a complex of interactive processes leading to a series of adaptive changes, rather than as regime change" (p. 55). Likewise, Vlahos et al. (2017) questioned "clear-cut analytical separation between the three levels of the multilevel perspective, as well as the relevance of a bottom-up procedure as a prerequisite for niche emergence vis-à-vis policy induced change" (p. 43). Lawhon and Murphy (2012) formulated four critiques to MLP related to the way it addresses social and political relations, participation, geography and power. Agency seems one of the main weaknesses of MLP. Isgren and Ness (2017), Stahlbrand (2016) and Vivero-Pol (2017) called for more room of agency within MLP. Isgren and Ness (2017) and Stahlbrand (2016) highlighted the important role of civil society collective action in agro-food sustainability transitions. This is in line with the critique formulated by Hargreaves et al. (2011) who argue that MLP tends to focus on market actors while neglecting civil society ones. Stahlbrand (2016) also pinpointed the essential contribution of public institutions. Konefal (2015) pointed out that MLP under-theorises governance role in sustainability transitions by highlighting the role played by multi-stakeholder initiatives in agricultural regime change in the USA.

\subsection{Transition management}

Transition management (TM) approach emerged from the aspiration to develop management tools and instruments to support system transformation. The focus of papers using TM is, generally, broader than in the case of MLP. In fact, papers focus on building visions for sustainable agro-food systems and actions needed to move towards such an envisioned system. Selected papers address transition in production (Beers et al. 2014; de Olde et al. 2017; Grin 2012; Hoppe et al. 2016; Pant et al. 2014), processing (Long et al. 2018; Rosin et al. 2017), consumption (Vinnari and Vinnari 2014; Vitters $\emptyset$ and Tangeland 2015) or in 
Table 6 Transition management in research on agro-food sustainability transitions

\begin{tabular}{lll}
\hline References & Case study & Country \\
\hline Beers et al. (2014) & Mixed farming & The Netherlands \\
Crivits et al. (2017) & Agro-food governance network & Belgium \\
de Olde et al. (2017) & Pig farming & The Netherlands \\
Gorissen et al. (2018) & Urban food system & Belgium \\
Grin (2012) & Dutch agriculture in the post-World War II & The Netherlands \\
Halbe et al. (2015) & Water-energy-food nexus & Cyprus \\
Hansen and Bjørkhaug (2017) & Bioeconomy & Norway \\
Hoppe et al. (2016) & Phosphorus and nitrogen management & Multi-country (The \\
& & Netherlands and \\
Kuhmonen (2017) & & Finland) \\
Long et al. (2018) & Potential of futures images in food system transition & Finland \\
Pant et al. (2014) & Food and beverage industry & The Netherlands \\
Rosin et al. (2017) & Transformation in subsistence farming & Nepal \\
van Gameren et al. (2015) & Sustainable wine production & New Zealand \\
Vinnari and Vinnari (2014) & Plant-based diets & Belgium \\
Vitters $\varnothing$ and Tangeland (2015) & Organic food & Undefined \\
\hline
\end{tabular}

the whole food system (Crivits et al. 2017; Gorissen et al. 2018; Kuhmonen 2017; van Gameren et al. 2015). Other papers adopt a wider approach and deal with bioeconomy (Hansen and Bjørkhaug 2017) or water-energy-food nexus (Halbe et al. 2015). As in the case of MLP, affiliations of scholars as well location of case studies are north-biased (Table 6). TM approach was particularly used by Dutch researchers.

The main difference between papers using MLP and those referring to TM or SNM is that while the former focus on interactions between niches and regimes, the latter are more concerned with actors' capacity of triggering institutional transformation. TM emphasises the importance of creating shared visions in "transition arenas" before starting transition experiments (Rotmans et al. 2001; Kemp et al. 2007; Loorbach 2007; Schot and Geels 2008). A "transition arena" is a space where there is interaction between niche actors and change-inclined regime stakeholders (Rotmans and Loorbach 2009). De Olde et al. (2017) emphasised the role of collaborations between different involved stakeholders (e.g. farmers, policy-makers and researchers) in the success of transitions. Partnering is one of the mechanisms identified by Gorissen et al. (2018) to accelerate sustainability transitions in urban food systems. They also show that acceleration dynamics in the food domain are fuelled via multi-actor collaborations, in which coordination and reflexive governance play a crucial role. Long et al. (2018) found that collaboration with firm external actors (e.g. suppliers, government, customers) is crucial in determining the success of transition towards business models for sustainability in the Dutch food and beverage industry.

Crivits et al. (2017) showed that political representation in transition arenas affects the success of transition governance and management. Likewise, Grin (2012) pointed out that politics (see powering, legitimisation) may interfere with the governance of sustainability transition. Van Gameren et al. (2015) highlighted that socio-political configurations, institutional contexts and governance arrangements influence the nascent local food systems in Belgium and, consequently, sustainable food consumption transitions. Therefore, they put 
governance, politics and institutions at the centre of the debate on sustainable consumption. Hoppe et al. (2016) addressed resource politics in their critical analysis of the governance of phosphorus and nitrogen systems in Finland and the Netherlands. They show the crucial role played by policies in determining both merits and failures of system transition. Besides market failures, policy failures (e.g. lack of policy coordination) can prevent sustainability transitions.

The notions of experimentation and social learning (Wals 2007) are central in the literature on TM and SNM. Beers et al. (2014) pointed out that learning in transition experiments should not be limited to niche-internal learning processes as also social learning about the environment of transition experiments is crucial to effectively meet societal demands. Therefore, social learning can determine the success (or failure) of transition experiments. Linking social learning to societal environment and context can allow for an effective management of transition experiments and projects. Likewise, de Olde et al. (2017) highlighted the need for knowledge exchange between farmers, researchers and policy-makers to foster transition towards sustainable agriculture. Grin (2012) emphasised the need for learning during all transition phases. Learning requirements are different not only along the phases of transition but also for the various actors. Addressing actors' specific learning requirements is vital to achieve sustainability transition (Halbe et al. 2015).

Transition management approach also concentrates on alternative visions to influence the reference frames of regime actors (Schot and Geels 2008). Hansen and Bjørkhaug (2017) analysed the dialectic relation between visions and actor expectations. They highlight the importance of developing common visions, which represent the synthesis of the expectations of the different sectors (aquaculture, agriculture, fishery, biotechnology, forestry), to foster transition towards bioeconomy in Norway. Having a clear narrative and vision was identified by Long et al. (2018) as one of the factors that determine the success of transition towards sustainability by Dutch SMEs in the food and beverage sector.

Beers et al. (2014) argued that the transition management literature provides a limited elaboration on the processes of learning involved in transition experiments and journeys. Therefore, they recommend relating transition theory to Senge's Field of Change (Senge et al. 1994) in order to provide a more comprehensive approach to learning processes in transitions. Vitters $\varnothing$ and Tangeland (2015) related the TM and ecological modernisation theories to analyse transition towards sustainable consumption in the food system. Likewise, Pant et al. (2014) recommended to integrate transition management (cf. management of change) and adaptive management (cf. adaptation to change) in an "adaptive transition management" approach to foster agro-ecological transition in the Nepalese Karnali mountains. Vinnari and Vinnari (2014) argued that TM approach needs further development to suit the food consumption context; they build on transition management and its cyclical path (strategic, tactical, operational levels), to develop a transition management framework to elucidate transition to plant-based diets. Kuhmonen (2017) pointed out that transition management efforts should pay more attention to agency and structures in the food system. Likewise, Rosin et al. (2017) called for considering also non-human agency (e.g. sustainability standards and metrics) in agro-food transition management.

\subsection{Social practice approach}

There have been calls for more attention to demand and consumption at the individual, household and community level (Schot and Geels 2008). The Social Practices Approach (SPA) puts demand and consumption at the centre of stage in food sustainability transitions. 
Table 7 Social practice approach in research on agro-food sustainability transitions

\begin{tabular}{lll}
\hline References & Case study & Country \\
\hline Cohen and Ilieva (2015) & Shopping at farmers' markets & USA \\
Ely et al. (2016) & Maize production and consumption & China \\
Huttunen and Oosterveer (2017) & Agricultural fertilisation practices & Finland \\
Langendahl et al. (2016) & Food processing & UK \\
Liu et al. (2016) & Sustainable food consumption & China \\
Mylan et al. (2016) & Domestic food provisioning & UK \\
Paddock (2017) & Household food consumption & UK \\
Twine (2015) & Snacking & UK \\
Wonneck and Hobson (2017) & Food and yard waste recycling & Canada \\
\hline
\end{tabular}

Most of papers using the social practice theory focus on consumption stage. In general, also food provisioning and procurement are analysed in relation to consumption (Cohen and Ilieva 2015; Mylan et al. 2016). In fact, one strength of SPA is that it combines human agency (see consumers) and social structures (see provision systems) to analyse sustainable consumption (Liu et al. 2016). Nevertheless, there are some exceptions to the focus of SPA on consumption. For instance, Huttunen and Oosterveer (2017) use the practice theory to investigate agricultural fertilisation practices among Finnish farmers. Some papers address both consumption and production (Ely et al. 2016) (Table 7). As the framework deals mainly with consumption patterns, there is no clear-cut distinction between the different agriculture sub-sectors (crop production, animal production, fisheries/aquaculture).

Many papers focus on changing food practices in cities. Cohen and Ilieva (2015) highlighted the relation between socio-technical systems, such as food systems, and everyday practices. Doing so, they show the importance of changing shopping practices in transition towards a more sustainable food system in New York City. Their analysis also highlights that practices, as social constructs, are context specific and geographically distinct. Therefore, cities can foster sustainability transition by creating an enabling food environment. In fact, according to Cohen and Ilieva (2015), "Cities shape, support and normalize food practices, and in the process play an important role in transitioning the wider food system" (p. 199). Mylan et al. (2016) investigated domestic consumption-circular economy nexus by analysing the linkages between food provisioning, eating practices and household waste generation in three British cities (Bristol, London, Preston). They show that dynamics of domestic food consumption practices are central in waste production; therefore, they should be taken into consideration in the design and implementation of strategies for the reduction of waste by consumers. Mylan et al. (2016) suggested to "[...] shift from imagining consumers as 'users' of particular products or services, to conceptualisation as 'doers' of everyday activities". Also Paddock (2017) suggested a shift in the way of viewing consumers. In particular, she unpacks the notion of consumers acting as autonomous choice agents and highlights that food consumption practices are shaped by complex social, material and cultural factors. The author suggests to focus not only on the single practices themselves, but also on the relationships and interconnections between them. In this respect, changes in food practices can be an entry point for a broader transition towards more sustainable lifestyles. Paddock (2017) put that "It is in thinking about the nexus of practices that we might come to more novel and dynamic policy interventions for sustainable consumption" (p. 135). This resonates well with "practice-based spillover effects" of Wonneck and Hobson 
(2017). The authors show that a food and yard waste recycling pilot program in Calgary (Canada) had positive spillover effects on food shopping. This shows the connectedness of practices, which means that changes in one practice can have implications (either negative or positive) also on others. Targeting the shared elements of these "mutually evolving practices" (Wonneck and Hobson 2017) can bring about more significant benefits in terms of sustainability transitions in cities.

Instead of domestic household consumption, Twine (2015) focused on out of home food consumption and analyses snacking through the lens of practice theory. The author calls for moving beyond individualistic assumptions of consumers' behavioural change and "situate snacking as an eating practice with health implications that has emerged within the social, temporal, economic and cultural organisation of everyday life" (p. 1270). This shows once again that eating practices, as well as changes in eating practices, are affected by the social environment and context.

Ely et al. (2016) focused on the linkages between consumption and production in China. They discuss political, sociocultural and technological factors shaping transition as well as pathways of changes in maize consumption and production practices. Their analysis shows the increasingly central role of consumers in shaping production and consumption patterns. Also Liu et al. (2016) emphasised linkages between provision systems and sustainable consumption practices. The authors argue that "neither an 'individualist' nor a system- or structural perspective alone is sufficient for understanding and analysing the transition towards sustainable consumption" (p. 13) and apply SPA that combines human agency (cf. individualist perspective) and social structures (cf. system/structural perspective). They show that research on sustainable consumption in China focused in the last decades on increase in production efficiency, while it paid almost no attention to changes in consumers' behaviour.

While the majority of papers using SPA focus on consumption, Huttunen and Oosterveer (2017) dealt with production and Langendahl et al. (2016) dealt with food processing. Huttunen and Oosterveer (2017) showed the applicability of the practice theory also in analysing changes in production practices. They deal with agricultural fertilisation practices. By focusing on the meanings, competences and material constituents of the fertilisation practice, they analyse paths change and differentiation. The analysis shows that changes in fertilisation practices are affected by their performance. The authors point out that nudging changes in meaning is a good strategy to effect real changes in practices. Langendahl et al. (2016) drew on the practice theory to conceptualise as practices, sustainable innovation activities of a British firm operating in food processing. They highlight that one "[...] can usefully treat a firm as a flow of practices that either resist or otherwise accommodate new practices deemed more sustainable" (p. 105). That is to say that firm's practices (e.g. strategy making, procurement, production, marketing, sales, transport, estate management) can either present windows of opportunity or constitute obstacles to transition towards sustainability.

\subsection{Strategic niche management}

Strategic niche management (SNM) is still a marginal framework in research on agro-food sustainability transitions. SNM approach considers networking with actors beyond the niche and learning (both internal learning and social learning) crucial facets of successful niche development. In fact, articulation of expectations and visions, building of social networks, and learning at multiple levels are central processes in SNM approach (Roep and 
Table 8 Strategic niche management in research on agro-food sustainability transitions

\begin{tabular}{lll}
\hline References & Case study & Country \\
\hline Bhattarai and Pant (2013) & Gender mainstreaming in rural areas & Nepal \\
Hermans et al. (2013) & Environmental cooperatives & The Netherlands \\
Kirwan et al. (2013) & Big Lottery Local Food programme & UK (England) \\
Maye (2018) & Permaculture community & UK (England) \\
Raman and Mohr (2014) & Biofuels & Undefined \\
Rossi (2017) & Grassroots food innovations & Italy \\
Smith (2006) & Organic food & UK \\
\hline
\end{tabular}

Wiskerke 2004; Schot and Geels 2008). The focus of papers using SNM is on processes of early adoption of innovations and factors that determine successful niche development. SNM scholars also address the relation between radical niche innovations and socio-technical regimes that they aim to change. Selected papers deal mainly with crop production. They address different stages of the food chain. Some papers address other topics such as gender mainstreaming in rural areas (Bhattarai and Pant 2013) or biofuels (Raman and Mohr 2014). Both affiliations and study areas are dominated by the UK (Table 8).

Strategic niche management approach was used to investigate different types of niches and protected innovation spaces. Bhattarai and Pant (2013) integrated SNM with patriarchal bargains theory to highlight the importance of creating protected niches for gender mainstreaming in securing the rights of rural women in western Nepal. Hermans et al. (2013) used SNM to explain network dynamics of the environmental cooperatives of the Northern Frisian Woodlands (The Netherlands). They highlight the interaction between niche processes (e.g. vision building, experimentation) and network dynamics. The authors show that niche vision, its projects and experiments as well as structural characteristics of the niche network evolve over time. Successful niche experiments increase not only niche network size but also its connectedness. Nevertheless, network size is also affected by external factors such as government financial support.

Grassroots innovations are a recurring theme in research papers using SNM. Kirwan et al. (2013) used the example of the Big Lottery Local Food programme, promoting local food networks, to investigate the spread of grassroots and social niche innovations and their impacts in terms of strengthening the resilience of local communities in England. Also Maye (2018) focused on grassroots niches. He combines SNM and Communities of Practice theory to examine the development dynamics of the permaculture community as well as its attempts to influence the mainstream agro-food regime in general and its knowledge system in particular. He shows that while permaculture community has been rather successful in replicating and scaling up permaculture, permaculture translation into the agrofood regime resulted very challenging. The challenge arises from both the internal characteristics of the niche (see difficulty to explain and apply permaculture concept) as well as the resistance of the mainstream. Also Rossi (2017) focused on the transformative potential of grassroots food innovations in Italy. She shows that grassroots initiatives, as examples of bottom-up and inclusive social innovation, have had a significant contribution in shaping the Italian food culture and consumption practices. The success of these food-related niches can be explained by their dynamism, continuous innovation and networking efforts.

Articulation of expectations and visions is crucial in SNM approach as it provides direction for niche development and legitimates niche protection. Raman and Mohr (2014) 
Table 9 Innovation systems in research on agro-food sustainability transitions

\begin{tabular}{|c|c|c|}
\hline References & Case study & Country \\
\hline Long et al. (2016) & Climate-smart agriculture & $\begin{array}{l}\text { Multi-country (The Nether- } \\
\text { lands, France, Switzerland } \\
\text { and Italy) }\end{array}$ \\
\hline Pant (2014) & Food security strategies & Multi-country (Nepal, India) \\
\hline Prasad (2016) & System of Rice Intensification (SRI) & India \\
\hline Randelli and Rocchi (2017) & Food industry & Italy \\
\hline Sixt et al. (2018) & Rainfed agriculture & Jordan \\
\hline Turner et al. (2017) & Community for change in agriculture & New Zealand \\
\hline Van Mierlo et al. (2013) & Poultry & The Netherlands \\
\hline
\end{tabular}

analysed how networks, visions and learning about biofuels have been shaped over time. For instance, the food versus fuel conflict has not been envisioned by promoters of biofuels in the aftermath of the 1970s oil shocks. The authors also highlight that it is important to also consider space and geography in order to better comprehend of dynamics of niche development.

Like the other frameworks, SNM has been critically discussed. Lachman (2013) questioned the effectiveness of SNM tools in managing sustainability transitions. Smith (2006) focused on the dialectical relation between niches and socio-technical regimes taking as an example that of organic food in the UK. In particular, he addresses the issue of niche-regime compatibility and its effect on the successful diffusion of niche innovations. In fact, the SNM literature points out that the success of a niche in transforming the regime is higher in case of good compatibility with the regime, while such a compatibility would mean a low transformative potential of the niche.

\subsection{Innovation systems}

The use of innovation systems approach in research on agro-food sustainability transitions is rather limited. Technological innovation system (Randelli and Rocchi 2017; Sixt et al. 2018 ) is the most prominent framework in innovations systems family, but some papers refer also to agricultural innovations systems (Turner et al. 2017) or regional innovations systems (van den Heiligenberg et al. 2017).

The focus of selected papers is on weaknesses in innovation networks, institutional failures and infrastructure failures that explain the limited dissemination and adoption of niche innovations as well as how these mechanisms are affected by interactions among actors. In particular, they analyse interaction among different actors in sustainability transitions journeys and institutional contexts and environments under which interaction takes place (Klerkx et al. 2010). The selected papers deal mainly with production (Long et al. 2016; Prasad 2016; Sixt et al. 2018) and processing (Randelli and Rocchi 2017) stages of the food chain (Table 9).

Long et al. (2016) explored socio-economic barriers and bottlenecks to diffusion and adoption of climate-smart agriculture (CSA) in France, Italy, Switzerland and the Netherlands. They show that barriers exist on demand (users) and supply (technology providers) sides of the technological innovation chain, which implies that policy-makers should collaborate with both CSA technological innovations producers and potential end users (e.g. 
farmers). While Long et al. (2016) focused on the diffusion of technological innovations (see CSA), Pant (2014) criticised the focus on technological innovation in food security strategies. By analysing the cases of Nepal and India, he argues that "The competence challenges of developing countries to make use of available agricultural resources are ecological, technological and learning-oriented in nature" (p. 340); therefore, "Technological innovation is necessary but not sufficient to achieve food security" (p. 336). The author concludes that developing countries cannot succeed in achieving food security unless technological competences are complemented by learning and agro-ecological competences. Prasad (2016) highlighted the importance of social innovation in agricultural sustainability transitions. He analyses the example of the System of Rice Intensification (SRI) in India and points out that social agro-ecological innovation networks can help creating possibilities for change from outside the mainstream. The author argues that heterogeneous networks (including civil society organisations, farmers, researchers) provide opportunities for the articulation of an inclusive and participative sustainability transition within agriculture.

System failures and blocking mechanisms are a recurring theme in the literature on innovation systems. Sixt et al. (2018) analysed systemic problems for transitions in water harvesting and rainfed agricultural production in Jordan. They show that the main interlocking blocking mechanisms in the water harvesting TIS are related to financing, planning and institutional structure, and highlight the need for integrated policy interventions to address them. Turner et al. (2017) explored a multi-actor, iterative and reflexive process to develop a common understanding of problems hampering system innovation in an agricultural innovation system (AIS) in New Zealand. The process fostered engagement among actors and led them to identify actions to stimulate system innovation and challenge dominant practices and institutional logics. The authors highlight that collective system analyses and involvement of multiple actors from AIS are beneficial in triggering agriculture transition. Also Van Mierlo et al. (2013) highlighted the relevance of collective and multi-actor analyses of structural and systemic barriers to system innovation towards sustainability, but they also underline the crucial role of system learning in sustainability transition in the Dutch poultry sector. They point out that "The innovation system perspective broadens the scope of the system and helps to distinguish the structures underlying current unsustainable practices" (p. 29).

Randelli and Rocchi (2017) applied the TIS approach to food industry in Italy and argued for explicitly considering "[...] consumers and producers as interacting and then co-evolving actors" (p. 94) in alternative food networks, which act as innovative systems in sustainability transitions journeys. Consumers are active agents that are central in shaping new paths towards sustainability. As in the case of Long et al. (2016), their analyses highlight the importance of considering both demand and supply elements in the innovation system.

\subsection{Integration of transition frameworks}

Many authors highlighted the need for integration of transition frameworks in order to better understand and nurture sustainability transitions (Markard and Truffer 2008; Meelen and Farla 2013; Shove 2003). For instance, the analytical framework proposed by El Bilali and Probst (2017) to map sustainability transitions in agro-food systems plugs in MLP elements of TM, SNM and innovation systems. Synthesising transition approaches would allow benefiting from their different strengths in the study of transitions. 
Table 10 Integration of transition frameworks in research on agro-food sustainability transitions

\begin{tabular}{|c|c|c|c|}
\hline Frameworks combined & References & Case study & Country \\
\hline \multirow[t]{3}{*}{ MLP and SPA } & Crivits and Paredis (2013) & $\begin{array}{l}\text { Local food systems (food } \\
\text { teams) }\end{array}$ & Belgium \\
\hline & Hargreaves et al. (2013) & Organic agriculture & UK \\
\hline & Hinrichs (2014) & Food systems & Undefined \\
\hline \multirow[t]{2}{*}{ MLP and SNM } & Pitt and Jones (2016) & $\begin{array}{l}\text { Food for Life (FFL) catering } \\
\text { mark }\end{array}$ & UK \\
\hline & Wiskerke (2003) & Wheat and bread & The Netherlands \\
\hline \multirow[t]{2}{*}{ TM and SPA } & Davies (2014) & Eating practices & Ireland \\
\hline & Davies and Doyle (2015) & $\begin{array}{l}\text { Household food consump- } \\
\text { tion }\end{array}$ & Ireland \\
\hline TM and IS & $\begin{array}{l}\text { van den Heiligenberg et al. } \\
\text { (2017) }\end{array}$ & Food & Multi-country/Europe \\
\hline
\end{tabular}

Different combinations of transition frameworks are present in the selected research papers: MLP and SNM (Wiskerke 2003; Pitt and Jones 2016), MLP and SPA (Crivits and Paredis 2013; Hargreaves et al. 2013; Hinrichs 2014), TM and IS (van den Heiligenberg et al. 2017), TM and SPA (Davies 2014; Davies and Doyle 2015) (Table 10). It is noteworthy that MLP is the framework that was more widely combined with other transition heuristics. This might be due not only to the fact that MLP is by far the most prominent framework in agro-food sustainability transition studies but also that it has been at the centre of the ongoing debate and controversies in the research field (e.g. Geels 2011). In fact, MLP is transversal in the research field and has many similarities, as well as complementarities, with TM and SNM. Moreover, the increasing use of SPA in agro-food transition research was somehow a critical response to the "verticality" of MLP.

It is widely recognised that social practices are fundamentally intertwined with sociotechnical systems. Therefore, MLP is increasingly complemented with approaches that give more importance to human-related and social factors in sustainability transitions such as SPA. According to Geels (2011), the concepts of "regimes" in MLP and "routinised practices" in SPA are similar. However, while the MLP privileges a vertical analytical lens, SPA considers a more horizontal perspective by analysing continuities and possible ruptures in everyday practices (Hinrichs 2014). Crivits and Paredis (2013) developed an "applied practice approach" that combines the concept of "practice" (cf. SPA) with that of "niche/regime" (cf. MLP) and argued that "This re-combination adds to the field of applied consumption research and describes consumption beyond the boundaries of individualist and structuralist models, as well as integrates a conceptualization of the a-linear reproduction of aligning and competing consumer practices" (p. 306). Hinrichs (2014) identified MLP and SPA as the main approaches in the research field of sustainability transitions and argued that "Taken together, these approaches offer different and useful ways to think about the dynamics, durability and significance of innovations in food and agriculture, and the part they play in transitions to sustainability" (p. 143). Likewise, Hargreaves et al. (2013) identified many intersection points and crossovers between regimes (cf. MLP) and practices (cf. SPA) and recommended integrating both approaches to better comprehend transition processes. According to the authors, the flat ontology of SPA makes it a fruitful complementary to MLP; MLP is primarily concerned with transitions in socio-technical regimes and SPA is concerned with transition in practices. Therefore, the authors connect 
regimes (cf. MLP) and practices (cf. SPA) to address transition towards food and nutrition security.

Pitt and Jones (2016) and Wiskerke (2003) referred to both MLP and SNM in their sustainability transitions studies. Pitt and Jones (2016) analysed processes of scaling up and out as a form of policy transfer that is crucial in food sustainability transitions and pointed out that "Policy decisions are significant to transition because policy convergence might create pressure for regime change or facilitate strategic niche management" (p. 4). Wiskerke (2003) analysed the development and stabilisation of the Dutch wheat regime (cf. inspection service, wheat breeders' legal rights, binding list of recommended wheat varieties) and the dynamics of emergence of a promising alternative, sustainable baking wheat cultivation system (Zeeuwse Vlegel in Zeeland province). The analysis shows the effects of changing European agriculture landscape on both regime and niche as well as dialectic interactions between niche and regime.

Besides integration with MLP, social practice theory was also combined with TM approach by Davies (2014) and Davies and Doyle (2015). Davies (2014) drew on “... insights from a participatory backcasting process that adopted a practice orientation within an overarching transitions framework" (p. 181) in her analysis of the role of interaction between citizen-consumer and technology (in particular ICTs) in shaping and co-creating future eating practices. Doing so, she situates eating practices at the heart of transition management processes. Also Davies and Doyle (2015) referred to a "practice-oriented participatory (POP) backcasting process"-allowing interdisciplinary interaction, creative innovation and collaborative learning - to give more value to governance and everyday consumption practices in transition planning and visions about sustainable food futures. POP backcasting method combines practice thinking and transition approach.

Some researchers have made efforts to integrate innovation systems and socio-technical transition approaches (MLP, TM, SNM) to better conceptualise linkages between emerging innovations and established regimes (Markard and Truffer 2008; Meelen and Farla 2013). Van den Heiligenberg et al. (2017) combined insights from the TM and regional innovation systems literature to analyse factors that determine the success (or failure) of innovation upscaling processes in inducing sustainability transitions and regime change. They conclude that success factors are related to the transition experiments themselves as well as to contexts/habitats in which they take place, but the involvement of users in the innovation experiments is the most important factor. The authors highlight the importance of the active collaboration between innovators/entrepreneurs, users and governments to foster sustainability transitions.

\section{Conclusions}

Scholars agree that there is not one right way to investigate transitions as socio-technical transitions are a complex and multi-faceted research topic. The diversity of transition frameworks accommodates the diversity of transition pathways and the plural form of "sustainability transitions" as well as the different perspectives, scopes and levels of sustainability transitions analyses. This paper reviewed the main transition frameworks that are used to understand and foster sustainability transitions in agro-food systems. Reviewed frameworks include the multi-level perspective (MLP), transition management (TM), strategic niche management (SNM), innovation systems (IS) and the Social Practices Approach (SPA). These sustainability transitions frameworks differ in terms 


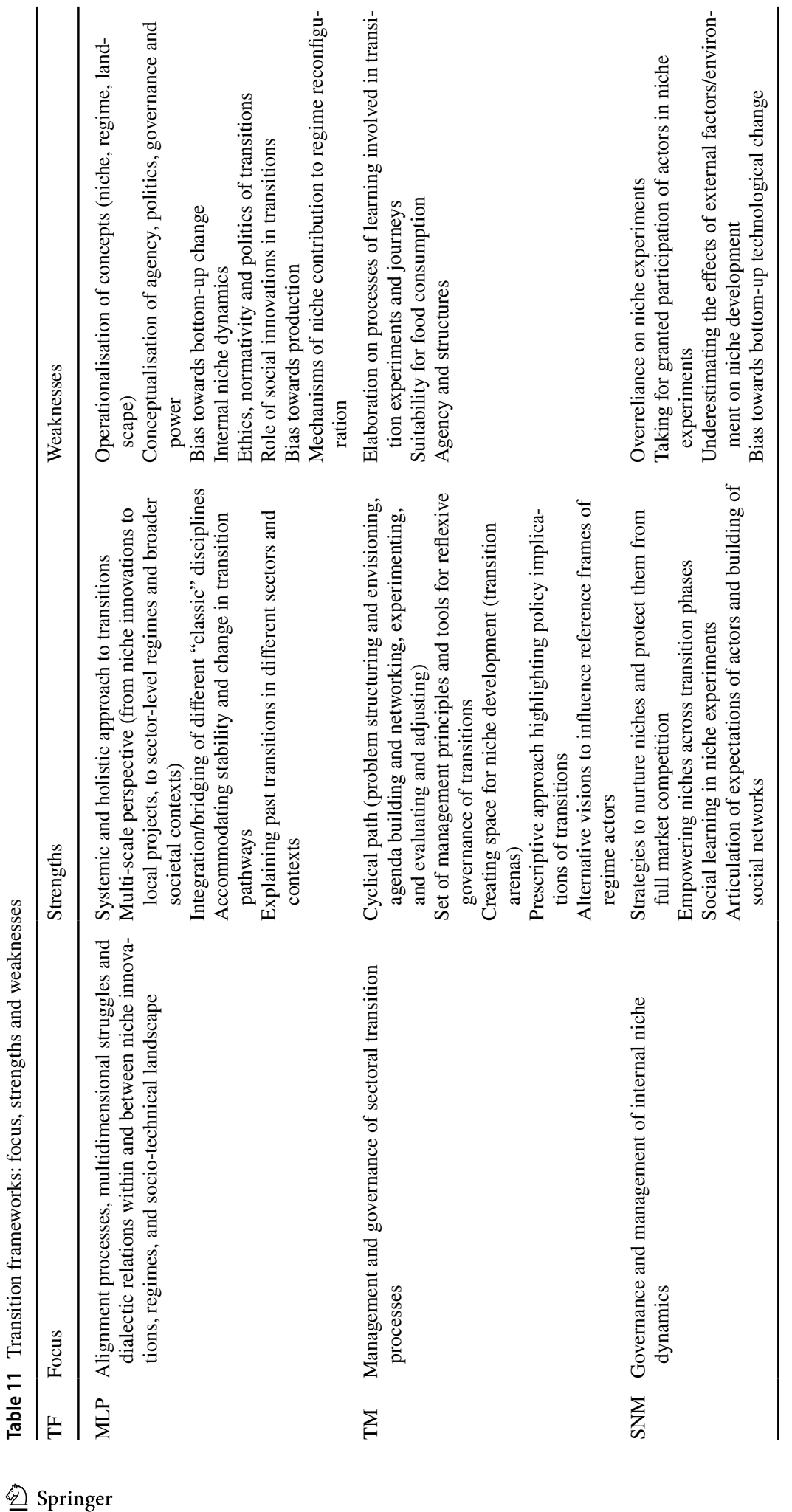




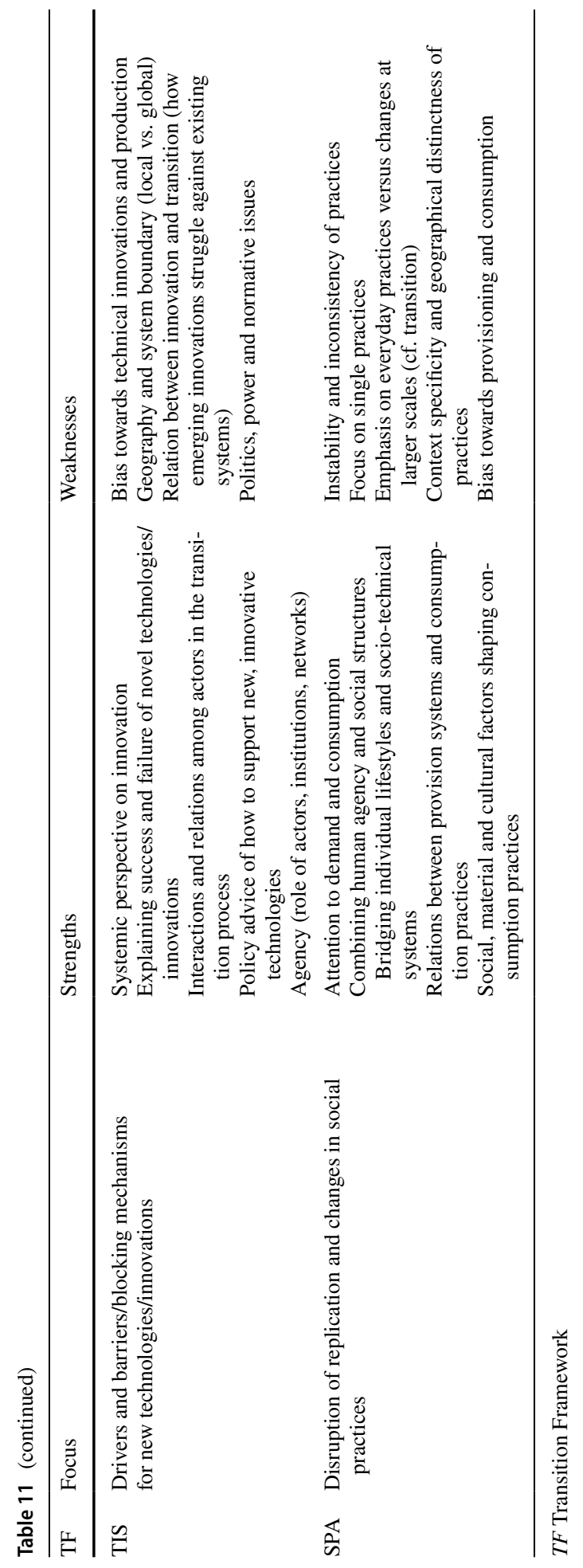


of epistemologies, assumptions or methodologies, but alert to the interconnections and complexities in promoting and nurturing any shift towards greater sustainability in the agro-food system. Furthermore, they offer useful ways to think about innovation dynamics in the agro-food arena as well as the role that innovation plays in agro-food sustainability transitions. The MLP is now the leading framework in the agro-food sustainability transition research field, but it is increasingly complemented with other approaches. The literature does not provide consensus on the best approach, and each of the reviewed frameworks has its strengths as well as its critics (Table 11). Therefore, the paper makes the case for more integration of these frameworks and approaches in order to better nurture and foster transitions towards sustainable agro-food systems. Integrating the frameworks outlined in this paper and developing an integrated heuristic framework, that is more adapted to the agro-food system, would represent a substantial contribution to and a significant breakthrough in agro-food sustainability transitions research field.

Acknowledgements Open access funding provided by the University of Natural Resources and Life Sciences, Vienna (BOKU).

\section{Compliance with ethical standards}

Conflict of interest The author declares that he has no conflict of interest.

Open Access This article is distributed under the terms of the Creative Commons Attribution 4.0 International License (http://creativecommons.org/licenses/by/4.0/), which permits unrestricted use, distribution, and reproduction in any medium, provided you give appropriate credit to the original author(s) and the source, provide a link to the Creative Commons license, and indicate if changes were made.

\section{References}

Alrøe, H., Sautier, M., Legun, K., Whitehead, J., Noe, E., Moller, H., et al. (2017). Performance versus values in sustainability transformation of food systems. Sustainability, 9(3), 332. https://doi. org/10.3390/su9030332.

Audet, R., Lefèvre, S., Brisebois, É., \& El-Jed, M. (2017). Structuring tensions and key relations of montreal seasonal food markets in the sustainability transition of the agri-food sector. Sustainability, 9(3), 320. https://doi.org/10.3390/su9030320.

Beers, P. J., Hermans, F., Veldkamp, T., \& Hinssen, J. (2014). Social learning inside and outside transition projects: Playing free jazz for a heavy metal audience. NJAS - Wageningen Journal of Life Sciences, 69, 5-13. https://doi.org/10.1016/j.njas.2013.10.001.

Beers, P. J., Veldkamp, A., Hermans, F., van Apeldoorn, D., Vervoort, J. J. M., \& Kok, K. (2010). Future sustainability and images. Futures, 42(7), 723-732. https://doi.org/10.1016/j.futures.2010.04.017.

Bergek, A., Jacobsson, S., Carlsson, B., Lindmark, S., \& Rickne, A. (2008). Analyzing the functional dynamics of technological innovation systems: A scheme of analysis. Research Policy, 37(3), 407-429. https://doi.org/10.1016/j.respol.2007.12.003.

Bhattarai, K., \& Pant, L. (2013). Patriarchal bargains in protected spaces: A new strategy for agricultural and rural development innovation in the western hills of Nepal. Canadian Journal of Development Studies/Revue canadienne d'études du développement, 34(4), 461-481. https://doi. org/10.1080/02255189.2013.830967.

Bonomi, S., Ricciardi, F., \& Rossignoli, C. (2017). Network organisations for externality challenges: How social entrepreneurship co-evolves with ICT-enabled solutions. International Journal of Knowledge-Based Development, 8(4), 346. https://doi.org/10.1504/ijkbd.2017.088183.

Bui, S., Cardona, A., Lamine, C., \& Cerf, M. (2016). Sustainability transitions: Insights on processes of niche-regime interaction and regime reconfiguration in agri-food systems. Journal of Rural Studies, 48, 92-103. https://doi.org/10.1016/j.jrurstud.2016.10.003.

Bush, S. R., \& Marschke, M. J. (2014). Making social sense of aquaculture transitions. Ecology and Society, 19(3), 50. https://doi.org/10.5751/es-06677-190350. 
Callon, M. (1999). Actor-network theory-The market test. The Sociological Review, 47, 181-195. https ://doi.org/10.1111/j.1467-954x.1999.tb03488.x.

Carlsson, B., \& Stankiewicz, R. (1991). On the nature, function and composition of technological systems. Journal of Evolutionary Economics, 1(2), 93-118. https://doi.org/10.1007/bf01224915.

Chiffoleau, Y., Millet-Amrani, S., \& Canard, A. (2016). From short food supply chains to sustainable agriculture in urban food systems: Food democracy as a vector of transition. Agriculture, 6(4), 57. https:// doi.org/10.3390/agriculture6040057.

Clear, A. K., O'neill, K., Friday, A., \& Hazas, M. (2016). Bearing an open "Pandora's Box": HCI for reconciling everyday food and sustainability. ACM Transactions on Computer-Human Interaction, 23(5), 1-25. https://doi.org/10.1145/2970817.

Cohen, N., \& Ilieva, R. T. (2015). Transitioning the food system: A strategic practice management approach for cities. Environmental Innovation and Societal Transitions, 17, 199-217. https://doi.org/10.1016/j. eist.2015.01.003.

Crivits, M., de Krom, M. P. M., Dessein, J., \& Block, T. (2017). Discursive representation within the institutional void: The rise and fall of a governance network on sustainable food in Belgium. Sociologia Ruralis. https://doi.org/10.1111/soru.12162.

Crivits, M., \& Paredis, E. (2013). Designing an explanatory practice framework: Local food systems as a case. Journal of Consumer Culture, 13(3), 306-336. https://doi.org/10.1177/1469540513484321.

Cross, R., \& Ampt, P. (2017). Exploring agroecological sustainability: Unearthing innovators and documenting a community of practice in Southeast Australia, 30(5), 585-600. https://doi. org/10.1080/08941920.2016.1230915.

Darnhofer, I. (2015). Socio-technical transitions in farming: Key concepts. In L.-A. Sutherland, I. Darnhofer, G. Wilson, \& L. Zagata (Eds.), Transition pathways towards sustainability in agriculture. Case studies from Europe (pp. 17-31). Wallingford: CABI.

das Chagas Oliveira, F., Calle Collado, A., \& Carvalho Leite, L. F. (2012). Peasant innovations and the search for sustainability: The case of Carnaubais Territory in Piauí State, Brazil. Journal of Sustainable Agriculture. https://doi.org/10.1080/10440046.2012.656342.

Davidson, D. J., Jones, K. E., \& Parkins, J. R. (2016). Food safety risks, disruptive events and alternative beef production: A case study of agricultural transition in Alberta. Agriculture and Human Values, 33(2), 359-371. https://doi.org/10.1007/s10460-015-9609-8.

Davies, A. R. (2014). Co-creating sustainable eating futures: Technology, ICT and citizen-consumer ambivalence. Futures, 62, 181-193. https://doi.org/10.1016/j.futures.2014.04.006.

Davies, A. R., \& Doyle, R. (2015). Transforming household consumption: From backcasting to homelabs experiments. Annals of the Association of American Geographers, 105(2), 425-436. https://doi. org/10.1080/00045608.2014.1000948.

Davies, A. R., \& Legg, R. (2018). Fare sharing: Interrogating the nexus of ICT, urban food sharing, and sustainability. Food, Culture and Society, 21(2), 233-254. https://doi.org/10.1080/15528014.2018.1427924.

de Olde, E. M., Carsjens, G. J., \& Eilers, C. H. A. M. (2017). The role of collaborations in the development and implementation of sustainable livestock concepts in The Netherlands. International Journal of Agricultural Sustainability, 15(2), 153-168. https://doi.org/10.1080/14735903.2016.1193423.

Dedeurwaerdere, T., De Schutter, O., Hudon, M., Mathijs, E., Annaert, B., Avermaete, T., et al. (2017). The governance features of social enterprise and social network activities of collective food buying groups. Ecological Economics, 140, 123-135. https://doi.org/10.1016/j.ecolecon.2017.04.018.

Duru, M., Fares, M., \& Therond, O. (2014). A conceptual framework for thinking now (and organising tomorrow) the agroecological transition at the level of the territory. Cahiers Agricultures, 23(2), 84-95. https://doi.org/10.1684/agr.2014.0691.

El Bilali, H., Callenius, C., Strassner, C., \& Probst, L. (2018). Food and nutrition security and sustainability transitions in food systems. Food and Energy Security. https://doi.org/10.1002/fes3.154.

El Bilali, H., \& Probst, L. (2017). Towards an integrated analytical framework to map sustainability transitions in food systems. AgroFor International Journal, 2(2), 24-32.

Ely, A., Geall, S., \& Song, Y. (2016). Sustainable maize production and consumption in China: Practices and politics in transition. Journal of Cleaner Production, 134(Part A), 259-268. https://doi. org/10.1016/j.jclepro.2015.12.001.

Elzen, B., \& Bos, B. (2016). The RIO approach: Design and anchoring of sustainable animal husbandry systems. Technological Forecasting and Social Change. https://doi.org/10.1016/j.techfore.2016.05.023.

Elzen, B., Geels, F. W., \& Green, K. (2004). System innovation and the transition to sustainability: Theory, evidence and policy. Cheltenham: Edward Elgar Publishing.

Elzen, B., Geels, F. W., Leeuwis, C., \& van Mierlo, B. (2011). Normative contestation in transitions 'in the making': Animal welfare concerns and system innovation in pig husbandry. Research Policy, 40(2), 263-275. https://doi.org/10.1016/j.respol.2010.09.018. 
European Environment Agency. (2016). Sustainability transitions: Now for the long term. Copenhagen: European Environment Agency.

European Environment Agency. (2018). Perspectives on transitions to sustainability. Copenhagen: European Environment Agency. https://doi.org/10.2800/10240.

Falcone, P. M. (2014). Sustainability transitions: A survey of an emerging field of research. Environmental Management and Sustainable Development, 3(2), 61. https://doi.org/10.5296/emsd.v3i2.6239.

FAO. (2014). Building a common vision for sustainable food and agriculture-Principles and approaches. Rome: FAO.

Fauchald, P., Hausner, V. H., Schmidt, J. I., \& Clark, D. A. (2017). Transitions of social-ecological subsistence systems in the Arctic. International Journal of the Commons, 11(1), 275-329. https://doi. org/10.18352/ijc.698.

Ferguson, P. (2016). Productivity growth as a barrier to a sustainability transition. Environmental Innovation and Societal Transitions, 20, 86-88. https://doi.org/10.1016/j.eist.2015.10.003.

Fischer-Kowalski, M. (2011). Analyzing sustainability transitions as a shift between socio-metabolic regimes. Environmental Innovation and Societal Transitions, 1(1), 152-159. https://doi.org/10.1016/j. eist.2011.04.004.

Fischer-kowalski, M., \& Rotmans, J. (2009). Conceptualizing, observing, and influencing social-Ecological transitions. Ecology and Society, 14(2), 3. http://www.ecologyandsociety.org/vol14/iss2/art3.

Foresight. (2011). The future of food and farming. London: Final Project Report.

Foxon, T. (2008). Managing the transition to renewable energy: Theory and practice from local, regional and macro perspectives. Environmental Sciences, 5(4), 286-288. https://doi.org/10.1080/15693430802469683.

Freeman, C., \& Perez, C. (1988). Structural crises of adjustment, business cycles and investment behaviour. In G. Dosi, C. Freeman, R. Nelson, G. Silverberg, \& L. L. Soete (Eds.), Technical change and economic theory. London: Pinter.

Freibauer, A., Mathijs, E., Brunori, G., Damianova, Z., Faroult, E., i Gomis, J. G., et al. (2011). Sustainable food consumption and production in a resource-constrained world. Euroepean Commission - Standing Committee on Agricultural Research (SCAR). The Third SCAR Foresight Exercise, https://ec.europ a.eu/research/scar/pdf/scar_3rd-foresight_2011.pdf. https://doi.org/10.2777/49719. Accessed 21 March 2017.

Garnett, T. (2014). Three perspectives on sustainable food security: Efficiency, demand restraint, food system transformation. What role for life cycle assessment? Journal of Cleaner Production. https://doi. org/10.1016/j.jclepro.2013.07.045.

Garnett, T., Appleby, M. C., Balmford, A., Bateman, I. J., Benton, T. G., Bloomer, P., et al. (2013). Sustainable intensification in agriculture: Premises and policies. Science, 341(6141), 33-34. https://doi. org/10.1126/science. 1234485 .

Geels, F. W. (2002). Technological transitions as evolutionary reconfiguration processes: A multi-level perspective and a case-study. Research Policy, 31(8-9), 1257-1274. https://doi.org/10.1016/s0048 $-7333(02) 00062-8$.

Geels, F. W. (2005a). Technological transitions and system innovations: A co-evolutionary and socio-technical analysis. Cheltenham: Edward Elgar Publishing.

Geels, F. W. (2005b). The dynamics of transitions in socio-technical systems: A multi-level analysis of the transition pathway from horse-drawn carriages to automobiles (1860-1930). Technology Analysis and Strategic Management. https://doi.org/10.1080/09537320500357319.

Geels, F. W. (2006). Co-evolutionary and multi-level dynamics in transitions: The transformation of aviation systems and the shift from propeller to turbojet (1930-1970). Technovation, 26(9), 999-1016. https:// doi.org/10.1016/j.technovation.2005.08.010.

Geels, F. W. (2010). Ontologies, socio-technical transitions (to sustainability), and the multi-level perspective. Research Policy, 39(4), 495-510. https://doi.org/10.1016/j.respol.2010.01.022.

Geels, F. W. (2011). The multi-level perspective on sustainability transitions: Responses to seven criticisms. Environmental Innovation and Societal Transitions, 1(1), 24-40. https://doi.org/10.1016/j. eist.2011.02.002.

Geels, F. W. (2018). Socio-technical transitions to sustainability. Oxford: Oxford University Press. https:// doi.org/10.1093/acrefore/9780199389414.013.587.

Geels, F. W., \& Schot, J. (2007). Typology of sociotechnical transition pathways. Research Policy, 36(3), 399-417. https://doi.org/10.1016/j.respol.2007.01.003.

Ghaffari, A., Bunch, M. J., MacRae, R. J., \& Zhao, S. J. (2015). Socio-economic support optimization for transition from conventional to organic farming using a spatiotemporal agent-based model. International Journal of Interdisciplinary Environmental Studies, 8(3-4), 13-25. 
Gilioli, G., Tikubet, G., Herren, H. R., \& Baumgärtner, J. (2015). Assessment of social-ecological transitions in a peri-urban Ethiopian farming community. International Journal of Agricultural Sustainability, 13(3), 204-221. https://doi.org/10.1080/14735903.2014.954452.

Gladek, E., Fraser, M., Roemers, G., Sabag Munoz, O., Hirsch, P., \& Kennedy, E. (2016). The global food system: An analysis. The Amsterdam, https://www.metabolic.nl/publications/global-foodsystem-analysis. Accessed 16 May 2018.

Godfray, H. C. J., Beddington, J. R., Crute, I. R., Haddad, L., Lawrence, D., Muir, J. F., et al. (2010a). Food security: The challenge of feeding 9 Billion people. Science, 327(5967), 812-818. https:// doi.org/10.1126/science.1185383.

Godfray, H. C. J., Crute, I. R., Haddad, L., Lawrence, D., Muir, J. F., Nisbett, N., et al. (2010b). The future of the global food system. Philosophical Transactions of the Royal Society of London. Series B, Biological Sciences, 365(1554), 2769-2777. https://doi.org/10.1098/rstb.2010.0180.

Gonzalez de Molina, M. (2013). Agroecology and politics. How to get sustainability? About the Necessity for a political agroecology. Agroecology and Sustainable Food Systems, 37(1), 45-59. https:// doi.org/10.1080/10440046.2012.705810.

Gorissen, L., Spira, F., Meynaerts, E., Valkering, P., \& Frantzeskaki, N. (2018). Moving towards systemic change? Investigating acceleration dynamics of urban sustainability transitions in the Belgian City of Genk. Journal of Cleaner Production, 173, 171-185. https://doi.org/10.1016/j.jclep ro.2016.12.052.

Grin, J. (2010). Understanding transitions from a governance perspective. In J. Grin, J. Rotmans, \& J. Schot (Eds.), Transitions to sustainable development. New directions in the study of long term structural change (pp. 223-314). New York: Routledge.

Grin, J. (2012). The politics of transition governance in Dutch agriculture. Conceptual understanding and implications for transition management. International Journal of Sustainable Development, 15(1/2), 72. https://doi.org/10.1504/ijsd.2012.044035.

Grin, J., Rotmans, J., Schot, J., Geels, F. W., \& Loorbach, D. (2010). Transitions to sustainable development: New directions in the study of long term transformative change. New York: Routhledge.

Halbe, J., Pahl-Wostl, C., Lange, M. A., \& Velonis, C. (2015). Governance of transitions towards sustainable development-The water-energy-food nexus in Cyprus. Water International, 40(5-6), 877-894. https://doi.org/10.1080/02508060.2015.1070328.

Hammond Wagner, C., Cox, M., \& Bazo Robles, J. L. (2016). Pesticide lock-in in small scale Peruvian agriculture. Ecological Economics, 129, 72-81. https://doi.org/10.1016/j.ecolecon.2016.05.013.

Hansen, L., \& Bjørkhaug, H. (2017). Visions and expectations for the Norwegian bioeconomy. Sustainability, 9(3), 341. https://doi.org/10.3390/su9030341.

Hargreaves, T. (2011). Practice-ing behaviour change: Applying social practice theory to proenvironmental behaviour change. Journal of Consumer Culture, 11(1), 79-99. https://doi. org/10.1177/1469540510390500.

Hargreaves, T., Haxeltine, A., Longhurst, N., \& Seyfang, G. (2011). Sustainability transitions from the bottom-up: Civil society, the multi-level perspective and practice theory. Working Paper-Centre for Social and Economic Research on the Global Environment, https://www.econstor.eu/obits tream/10419/48796/1/662352246.pdf. Accessed 23 June 2017.

Hargreaves, T., Longhurst, N., \& Seyfang, G. (2013). Up, down, round and round: Connecting regimes and practices in innovation for sustainability. Environment and Planning A, 45(2), 402-420. https ://doi.org/10.1068/a45124.

Hassink, J., Grin, J., \& Hulsink, W. (2013). Multifunctional agriculture meets health care: Applying the multi-level transition sciences perspective to care farming in The Netherlands. Sociologia Ruralis, 53(2), 223-245. https://doi.org/10.1111/j.1467-9523.2012.00579.x.

Hassink, J., Grin, J., \& Hulsink, W. (2018). Enriching the multi-level perspective by better understanding agency and challenges associated with interactions across system boundaries. The case of care farming in The Netherlands: Multifunctional agriculture meets health care. Journal of Rural Studies, 57, 186-196. https://doi.org/10.1016/j.jrurstud.2017.12.018.

Hassink, J., Hulsink, W., \& Grin, J. (2014). Farming with care: The evolution of care farming in The Netherlands. NJAS - Wageningen Journal of Life Sciences, 68, 1-11. https://doi.org/10.1016/j. njas.2013.11.001.

Hauser, M., \& Lindtner, M. (2017). Organic agriculture in post-war Uganda: Emergence of pioneer-led niches between 1986 and 1993. Renewable Agriculture and Food Systems, 32(02), 169-178. https ://doi.org/10.1017/s1742170516000132.

Hekkert, M. P., Suurs, R. A. A., Negro, S. O., Kuhlmann, S., \& Smits, R. E. H. M. (2007). Functions of innovation systems: A new approach for analysing technological change. Technological Forecasting and Social Change, 74(4), 413-432. https://doi.org/10.1016/j.techfore.2006.03.002. 
Hermans, F., Roep, D., \& Klerkx, L. (2016). Scale dynamics of grassroots innovations through parallel pathways of transformative change. Ecological Economics, 130, 285-295. https://doi. org/10.1016/j.ecolecon.2016.07.011.

Hermans, F., van Apeldoorn, D., Stuiver, M., \& Kok, K. (2013). Niches and networks: Explaining network evolution through niche formation processes. Research Policy, 42(3), 613-623. https://doi. org/10.1016/j.respol.2012.10.004.

Hinrichs, C. C. (2014). Transitions to sustainability: A change in thinking about food systems change? Agriculture and Human Values, 31(1), 143-155. https://doi.org/10.1007/s10460-014-9479-5.

Hoppe, T., Kuokkanen, A., Mikkilä, M., Kahiluoto, H., Kuisma, M., Arentsen, M., et al. (2016). System merits or failures? Policies for transition to sustainable P and N systems in The Netherlands and Finland. Sustainability, 8(5), 463. https://doi.org/10.3390/su8050463.

Hubeau, M., Marchand, F., Coteur, I., Mondelaers, K., Debruyne, L., \& Van Huylenbroeck, G. (2017). A new agri-food systems sustainability approach to identify shared transformation pathways towards sustainability. Ecological Economics, 131, 52-63. https://doi.org/10.1016/j.ecolecon.2016.08.019.

Huttunen, S., \& Oosterveer, P. (2017). Transition to sustainable fertilisation in agriculture, a practices approach. Sociologia Ruralis, 57(2), 191-210. https://doi.org/10.1111/soru.12118.

Immink, V. M., Reinders, M. J., Van Tulder, R. J. M., \& Van Trijp, J. C. M. (2013). The livestock sector and its stakeholders in the search to meet the animal welfare requirements of society. Journal on Chain and Network Science, 13(2), 151-160. https://doi.org/10.3920/jens2013.1005.

Ingram, J. (2015). Framing niche-regime linkage as adaptation: An analysis of learning and innovation networks for sustainable agriculture across Europe. Journal of Rural Studies, 40, 59-75. https://doi. org/10.1016/j.jrurstud.2015.06.003.

Ingram, J. (2018). Agricultural transition: Niche and regime knowledge systems' boundary dynamics. Environmental Innovation and Societal Transitions, 26, 117-135. https://doi.org/10.1016/j. eist.2017.05.001.

Ingram, J., Maye, D., Kirwan, J., Curry, N., \& Kubinakova, K. (2015). Interactions between Niche and Regime: An analysis of learning and innovation networks for sustainable agriculture across Europe. The Journal of Agricultural Education and Extension, 21(1), 55-71. https://doi.org/10.1080/13892 24x.2014.991114.

IPES-Food. (2015). The new science of sustainable food systems: Overcoming barriers to food systems reform. International Panel of Experts on Sustainable Food systems, www.ipes-food.org/images/ Reports/IPES_report01_1505_web_br_pages.pdf. Accessed 13 Feb 2017.

Isgren, E., \& Ness, B. (2017). Agroecology to promote just sustainability transitions: Analysis of a civil society network in the Rwenzori Region, Western Uganda. Sustainability, 9(8), 1357. https://doi. org/10.3390/su9081357.

Jacobs, B., Cordell, D., Chin, J., \& Rowe, H. (2017). Towards phosphorus sustainability in North America: A model for transformational change. Environmental Science \& Policy, 77, 151-159. https://doi. org/10.1016/j.envsci.2017.08.009.

Jacobsson, S., \& Bergek, A. (2011). Innovation system analyses and sustainability transitions: Contributions and suggestions for research. Environmental Innovation and Societal Transitions. https://doi. org/10.1016/j.eist.2011.04.006.

Järnberg, L., Enfors Kautsky, E., Dagerskog, L., \& Olsson, P. (2018). Green niche actors navigating an opaque opportunity context: Prospects for a sustainable transformation of Ethiopian agriculture. Land Use Policy, 71, 409-421. https://doi.org/10.1016/j.landusepol.2017.11.053.

Jehlička, P., \& Smith, J. (2011). An unsustainable state: Contrasting food practices and state policies in the Czech Republic. Geoforum, 42(3), 362-372. https://doi.org/10.1016/j.geoforum.2011.01.005.

Jurgilevich, A., Birge, T., Kentala-Lehtonen, J., Korhonen-Kurki, K., Pietikäinen, J., Saikku, L., et al. (2016). Transition towards circular economy in the food system. Sustainability, 8(1), 69. https://doi. org/10.3390/su8010069.

Kemp, R., Rotmans, J., \& Loorbach, D. (2007). Assessing the Dutch energy transition policy: How does it deal with dilemmas of managing transitions? Journal of Environmental Policy and Planning. https:// doi.org/10.1080/15239080701622816.

Kemp, R., Schot, J., \& Hoogma, R. (1998). Regime shifts to sustainability through processes of niche formation: The approach of strategic niche management. Technology Analysis \& Strategic Management, 10(2), 175-198. https://doi.org/10.1080/09537329808524310.

Kern, F. (2012). Using the multi-level perspective on socio-technical transitions to assess innovation policy. Technological Forecasting and Social Change, 79(2), 298-310. https://doi.org/10.1016/j.techf ore.2011.07.004. 
Kirwan, J., Ilbery, B., Maye, D., \& Carey, J. (2013). Grassroots social innovations and food localisation: An investigation of the Local Food programme in England. Global Environmental Change, 23(5), 830-837. https://doi.org/10.1016/j.gloenvcha.2012.12.004.

Klerkx, L., Aarts, N., \& Leeuwis, C. (2010). Adaptive management in agricultural innovation systems: The interactions between innovation networks and their environment. Agricultural Systems, 103(6), 390400. https://doi.org/10.1016/j.agsy.2010.03.012.

Konefal, J. (2015). Governing sustainability transitions: Multi-Stakeholder Initiatives and Regime Change in United States Agriculture. Sustainability, 7(1), 612-633. https://doi.org/10.3390/su701 0612 .

Kuhmonen, T. (2017). Exposing the attractors of evolving complex adaptive systems by utilising futures images: Milestones of the food sustainability journey. Technological Forecasting and Social Change, 114, 214-225. https://doi.org/10.1016/j.techfore.2016.08.015.

Kuokkanen, A., Mikkilä, M., Kuisma, M., Kahiluoto, H., \& Linnanen, L. (2017). The need for policy to address the food system lock-in: A case study of the Finnish context. Journal of Cleaner Production, 140, 933-944. https://doi.org/10.1016/j.jclepro.2016.06.171.

Lachman, D. A. (2013). A survey and review of approaches to study transitions. Energy Policy, 58, 269-276. https://doi.org/10.1016/j.enpol.2013.03.013.

Lang, T. (2009). Food security and sustainability: The perfect fit. London: Sustainable Development Commission (SDC).

Langendahl, P.-A., Cook, M., \& Potter, S. (2016). Sustainable innovation journeys: Exploring the dynamics of firm practices as part of transitions to more sustainable food and farming. Local Environment, 21(1), 105-123. https://doi.org/10.1080/13549839.2014.926869.

Latour, B. (2013). Reassembling the social. An introduction to actor-network-theory. Journal of Economic Sociology, 14(2), 73-87. https://doi.org/10.17323/1726-3247-2013-2-73-87.

Lawhon, M., \& Murphy, J. T. (2012). Socio-technical regimes and sustainability transitions. Progress in Human Geography, 36(3), 354-378. https://doi.org/10.1177/0309132511427960.

Lebel, L., Lebel, P., Garden, P., Giap, D. H., Khrutmuang, S., \& Nakayama, S. (2008). Places, chains, and plates: Governing transitions in the shrimp aquaculture production-consumption system. Globalizations, 5(2), 211-226. https://doi.org/10.1080/14747730802057589.

Levidow, L. (2015). European transitions towards a corporate-environmental food regime: Agroecological incorporation or contestation? Journal of Rural Studies, 40, 76-89. https://doi.org/10.1016/j. jrurstud.2015.06.001.

Levidow, L., Pimbert, M., \& Vanloqueren, G. (2014). Agroecological research: Conforming or transforming the dominant agro-food regime? Agroecology and Sustainable Food Systems, 38(10), 1127-1155. https://doi.org/10.1080/21683565.2014.951459.

Levkoe, C. Z. (2011). Towards a transformative food politics. Local Environment, 16(7), 687-705. https ://doi.org/10.1080/13549839.2011.592182.

Liu, W., Oosterveer, P., \& Spaargaren, G. (2016). Promoting sustainable consumption in China: A conceptual framework and research review. Journal of Cleaner Production, 134, 13-21. https://doi. org/10.1016/j.jclepro.2015.10.124.

Loconto, A., \& Barbier, M. (2017). Creating actionable knowledge for sustainability: A case of "standards in the making”. In M. Miele, V. Higgins, H. Bjørkhaug, \& M. Truninger (Eds.), Transforming the rural. Research in rural sociology and development (Vol. 24, pp. 115-133). Bingley: Emerald Publishing Limited. https://doi.org/10.1108/S1057-192220170000024006.

Long, T. B., Blok, V., \& Coninx, I. (2016). Barriers to the adoption and diffusion of technological innovations for climate-smart agriculture in Europe: Evidence from the Netherlands, France, Switzerland and Italy. Journal of Cleaner Production, 112, 9-21. https://doi.org/10.1016/j.jclep ro.2015.06.044.

Long, T. B., Looijen, A., \& Blok, V. (2018). Critical success factors for the transition to business models for sustainability in the food and beverage industry in the Netherlands. Journal of Cleaner Production, 175, 82-95. https://doi.org/10.1016/j.jclepro.2017.11.067.

Loorbach, D. (2007). Transition management: New mode of governance for sustainable development. Utrecht: International Books.

Loorbach, D. (2010). Transition management for sustainable development: A prescriptive, complexity-based governance framework. Governance, 23(1), 161-183. https://doi.org/10.111 1/j.1468-0491.2009.01471.x.

Loorbach, D., Frantzeskaki, N., \& Avelino, F. (2017). Sustainability transitions research: Transforming science and practice for societal change. Annual Review of Environment and Resources, 42(1), 599-626. https://doi.org/10.1146/annurev-environ-102014-021340. 
Loorbach, D., \& Rotmans, J. (2006). Managing transitions for sustainable development. In X. Olshoorn \& A. J. Wieczorek (Eds.), Understanding industrial transformation. Views from different disciplines. Dordrecht: Springer.

Loorbach, D., Van Der Brugge, R., \& Taanman, M. (2008). Governance in the energy transition: Practice of transition management in The Netherlands. International Journal of Environmental Technology and Management, 9(2/3), 294. https://doi.org/10.1504/ijetm.2008.019039.

Lutz, J., \& Schachinger, J. (2013). Do local food networks foster socio-ecological transitions towards food sovereignty? Learning from real place experiences. Sustainability, 5(11), 4778-4796. https:// doi.org/10.3390/su5114778.

Manuel-Navarrete, D., \& Gallopín, G. C. (2012). Feeding the world sustainably: Knowledge governance and sustainable agriculture in the Argentine Pampas. Environment, Development and Sustainability, 14(3), 321-333. https://doi.org/10.1007/s10668-011-9326-4.

Marco, I., Padró, R., Cattaneo, C., Caravaca, J., \& Tello, E. (2018). From vineyards to feedlots: a fundflow scanning of sociometabolic transition in the Vallès County (Catalonia) 1860-1956-1999. Regional Environmental Change, 18(4), 981-993. https://doi.org/10.1007/s10113-017-1172-y.

Markard, J. (2018). The life cycle of technological innovation systems. Technological Forecasting and Social Change. https://doi.org/10.1016/j.techfore.2018.07.045.

Markard, J., Raven, R., \& Truffer, B. (2012). Sustainability transitions: An emerging field of research and its prospects. Research Policy, 41(6), 955-967. https://doi.org/10.1016/j.respol.2012.02.013.

Markard, J., \& Truffer, B. (2008). Technological innovation systems and the multi-level perspective: Towards an integrated framework. Research Policy, 37(4), 596-615. https://doi.org/10.1016/j. respol.2008.01.004.

Marsden, T. (2013). From post-productionism to reflexive governance: Contested transitions in securing more sustainable food futures. Journal of Rural Studies, 29, 123-134. https://doi.org/10.1016/j. jrurstud.2011.10.001.

Maru, Y., Sparrow, A., Stirzaker, R., \& Davies, J. (2016). Integrated agricultural research for development (IAR4D) from a theory of change perspective. Agricultural Systems, 10, 100. https://doi. org/10.1016/j.agsy.2016.09.012.

Maye, D. (2018). Examining innovation for sustainability from the bottom up: An analysis of the permaculture community in England. Sociologia Ruralis, 58(2), 331-350. https://doi.org/10.1111/ soru. 12141 .

Meek, D. (2016). The cultural politics of the agroecological transition. Agriculture and Human Values, 33(2), 275-290. https://doi.org/10.1007/s10460-015-9605-z.

Meelen, T., \& Farla, J. (2013). Towards an integrated framework for analysing sustainable innovation policy. Technology Analysis \& Strategic Management, 25(8), 957-970. https://doi. org/10.1080/09537325.2013.823146.

Meynard, J.-M., Jeuffroy, M.-H., Le Bail, M., Lefèvre, A., Magrini, M.-B., \& Michon, C. (2017). Designing coupled innovations for the sustainability transition of agrifood systems. Agricultural Systems, 157, 330-339. https://doi.org/10.1016/j.agsy.2016.08.002.

Miles, A., DeLonge, M. S., \& Carlisle, L. (2017). Triggering a positive research and policy feedback cycle to support a transition to agroecology and sustainable food systems. Agroecology and Sustainable Food Systems, 41(7), 855-879. https://doi.org/10.1080/21683565.2017.1331179.

Minh, T. T., Friederichsen, R., Neef, A., \& Hoffmann, V. (2014). Niche action and system harmonization for institutional change: Prospects for demand-driven agricultural extension in Vietnam. Journal of Rural Studies, 36, 273-284. https://doi.org/10.1016/j.jrurstud.2014.09.008.

Moher, D., Liberati, A., Tetzlaff, J., Altman, D. G., \& The PRISMA Group. (2009). Preferred reporting items for systematic reviews and meta-analyses: The PRISMA statement. PLoS Medicine, 6(7), e1000097. https://doi.org/10.1371/journal.pmed.1000097.

Moore, J. (2015). ecological footprints and lifestyle archetypes: Exploring dimensions of consumption and the transformation needed to achieve urban sustainability. Sustainability, 7(4), 4747-4763. https://doi.org/10.3390/su7044747.

Moragues-Faus, A., \& Morgan, K. (2015). Reframing the foodscape: The emergent world of urban food policy. Environment and Planning A: Economy and Space, 47(7), 1558-1573. https://doi. org/10.1177/0308518x15595754.

Moraine, M., Grimaldi, J., Murgue, C., Duru, M., \& Therond, O. (2016). Co-design and assessment of cropping systems for developing crop-livestock integration at the territory level. Agricultural Systems, 147, 87-97. https://doi.org/10.1016/j.agsy.2016.06.002.

Morrissey, J. E., Mirosa, M., \& Abbott, M. (2014). Identifying transition capacity for agri-food regimes: Application of the multi-level perspective for strategic mapping. Journal of Environmental Policy \& Planning, 16(2), 281-301. https://doi.org/10.1080/1523908x.2013.845521. 
Mylan, J., Geels, F. W., Gee, S., McMeekin, A., \& Foster, C. (2015). Eco-innovation and retailers in milk, beef and bread chains: Enriching environmental supply chain management with insights from innovation studies. Journal of Cleaner Production, 107, 20-30. https://doi.org/10.1016/j. jclepro.2014.09.065.

Mylan, J., Holmes, H., \& Paddock, J. (2016). Re-introducing consumption to the 'Circular Economy': A sociotechnical analysis of domestic food provisioning. Sustainability, 8(12), 794. https://doi. org/10.3390/su8080794.

Negi, V. S., Maikhuri, R. K., Rawat, L. S., \& Bahuguna, A. (2009). Traditional agriculture in transition: A case of Har-ki Doon Valley (Govind Pashu Vihar Sanctuary and National Park) in Central Himalaya. International Journal of Sustainable Development and World Ecology, 16(5), 313-321. https://doi. org/10.1080/13504500903194739.

Nygaard, I., \& Bolwig, S. (2018). The rise and fall of foreign private investment in the jatropha biofuel value chain in Ghana. Environmental Science \& Policy, 84, 224-234. https://doi.org/10.1016/j.envsc i.2017.08.007.

O'Rourke, D., \& Lollo, N. (2015). Transforming consumption: From decoupling, to behavior change, to system changes for sustainable consumption. Annual Review of Environment and Resources, 40(1), 233-259. https://doi.org/10.1146/annurev-environ-102014-021224.

OECD. (2011). Towards green growth-A summary for policy makers. Paris: OECD. https://doi. org/10.1787/9789264111318-en.

Paddock, J. (2017). Household consumption and environmental change: Rethinking the policy problem through narratives of food practice. Journal of Consumer Culture, 17(1), 122-139. https://doi. org/10.1177/1469540515586869.

Pant, L. P. (2014). Critical systems of learning and innovation competence for addressing complexity in transformations to agricultural sustainability. Agroecology and Sustainable Food Systems, 38(3), 336365. https://doi.org/10.1080/21683565.2013.833157.

Pant, L. P. (2016). Paradox of mainstreaming agroecology for regional and rural food security in developing countries. Technological Forecasting and Social Change, 111, 305-316. https://doi.org/10.1016/j. techfore.2016.03.001.

Pant, L. P., Krishna Bahadur, K. C., Fraser, E. D. G., Shrestha, P. K., Lama, A. B., Jirel, S. K., et al. (2014). Adaptive transition management for transformations to agricultural sustainability in the Karnali Mountains of Nepal. Agroecology and Sustainable Food Systems, 38(10), 1156-1183. https://doi. org/10.1080/21683565.2014.942022.

Pantzar, M., \& Shove, E. (2010). Understanding innovation in practice: A discussion of the production and re-production of nordic walking. Technology Analysis \& Strategic Management, 22(4), 447-461. https://doi.org/10.1080/09537321003714402.

Papachristos, G., \& Adamides, E. (2016). A retroductive systems-based methodology for socio-technical transitions research. Technological Forecasting and Social Change, 108, 1-14. https://doi. org/10.1016/j.techfore.2016.04.007.

Paredis, E. (2011). Sustainability transitions and the nature of technology. Foundations of Science, 16(2-3), 195-225. https://doi.org/10.1007/s10699-010-9197-4.

Partzsch, L. (2017). Biofuel research: Perceptions of power and transition. Energy, Sustainability and Society, 7(1), 14. https://doi.org/10.1186/s13705-017-0116-1.

Pitt, H., \& Jones, M. (2016). Scaling up and out as a pathway for food system transitions. Sustainability, $8(10), 1025$. https://doi.org/10.3390/su8101025.

Prasad, S. C. (2016). Innovating at the margins: The system of rice intensification in india and transformative social innovation. Ecology and Society, 21(4), 7. https://doi.org/10.5751/es-08718-210407.

Quist, J., Thissen, W., \& Vergragt, P. J. (2011). The impact and spin-off of participatory backcasting: From vision to niche. Technological Forecasting and Social Change, 78(5), 883-897. https://doi. org/10.1016/j.techfore.2011.01.011.

Raman, S., \& Mohr, A. (2014). Biofuels and the role of space in sustainable innovation journeys. Journal of Cleaner Production, 65, 224-233. https://doi.org/10.1016/j.jclepro.2013.07.057.

Randelli, F., \& Rocchi, B. (2017). Analysing the role of consumers within technological innovation systems: The case of alternative food networks. Environmental Innovation and Societal Transitions, 25, 94-106. https://doi.org/10.1016/j.eist.2017.01.001.

Raven, R., \& Geels, F. W. (2010). Socio-cognitive evolution in niche development: Comparative analysis of biogas development in Denmark and the Netherlands (1973-2004). Technovation, 30(2), 87-99. https ://doi.org/10.1016/j.technovation.2009.08.006.

Reckwitz, A. (2002). Toward a theory of social practices: A development in culturalist theorizing. European Journal of Social Theory, 5(2), 243-263. https://doi.org/10.1177/13684310222225432. 
Rip, A., \& Kemp, R. (1998). Technological change. In S. Rayner \& E. L. Malone (Eds.), Human choice and climate change (Vol. 2, pp. 327-399). Columbus, OH: Battelle Press.

Rodríguez Morales, J. E., \& Rodríguez López, F. (2017). The political economy of bioenergy in the United States: A historical perspective based on scenarios of conflict and convergence. Energy Research \& Social Science, 27, 141-150. https://doi.org/10.1016/j.erss.2017.03.002.

Roep, D., \& Wiskerke, J. S. C. (2004). Reflecting on novelty production and niche management in agriculture. In J. Wiskerke \& J.-D. van der Ploeg (Eds.), Seeds of transition. Essays on novelty production, niches and regimes in agriculture (pp. 341-356). Assen: van Gorcum.

Rosin, C. J., Legun, K. A., Campbell, H., \& Sautier, M. (2017). From compliance to co-production: Emergent forms of agency in sustainable wine production in New Zealand. Environment and Planning A, 49(12), 2780-2799. https://doi.org/10.1177/0308518x17733747.

Rossi, A. (2017). Beyond food provisioning: The transformative potential of grassroots innovation around food. Agriculture, 7(12), 6. https://doi.org/10.3390/agriculture7010006.

Rotmans, J., Kemp, R., \& van Asselt, M. (2001). More evolution than revolution: Transition management in public policy. Foresight, 3(1), 15-31. https://doi.org/10.1108/14636680110803003.

Rotmans, J., \& Loorbach, D. (2009). Complexity and transition management. Journal of Industrial Ecology, 13(2), 184-196. https://doi.org/10.1111/j.1530-9290.2009.00116.x.

Santhanam-Martin, M., Ayre, M., \& Nettle, R. (2015). Community sustainability and agricultural landscape change: Insights into the durability and vulnerability of the productivist regime. Sustainability Science, 10(2), 207-217. https://doi.org/10.1007/s11625-014-0268-2.

Sartorius, C. (2006). Second-order sustainability-conditions for the development of sustainable innovations in a dynamic environment. Ecological Economics, 58(2), 268-286. https://doi.org/10.1016/j. ecolecon.2005.07.010.

Sautier, M., Legun, K. A., Rosin, C., \& Campbell, H. (2018). Sustainability: A tool for governing wine production in New Zealand? Journal of Cleaner Production, 179, 347-356. https://doi. org/10.1016/j.jclepro.2017.12.194.

Schandl, H., Fischer-Kowalski, M., Grunbuhel, C., \& Krausmann, F. (2009). Socio-metabolic transitions in developing Asia. Technological Forecasting and Social Change, 76(2), 267-281. https://doi. org/10.1016/j.techfore.2007.12.004.

Schot, J., \& Geels, F. W. (2008). Strategic niche management and sustainable innovation journeys: Theory, findings, research agenda, and policy. Technology Analysis \& Strategic Management, 20(5), 537-554. https://doi.org/10.1080/09537320802292651.

Schut, M., Klerkx, L., Sartas, M., Lamers, D., Campbell, M. M., Ogbonna, I., et al. (2016). Innovation platforms: Experiences with their institutional embedding in agricultural research for development. Experimental Agriculture, 52(04), 537-561. https://doi.org/10.1017/s001447971500023x.

Searchinger, T., Hanson, C., Ranganathan, J., Lipinski, B., Waite, R., Winterbottom, R., et al. (2013). Creating a sustainable food future: Interim findings. A menu of solutions to sustainably feed more than 9 billion people by 2050. Washington, DC: World Resources Institute (WRI).

Senge, P. M., Kleiner, A., Roberts, C., Ross, R. B., \& Smith, B. J. (1994). The fifth discipline fieldbook: Strategies and tools for building a learning organization. New York: Doubleday. https://doi. org/10.1108/eb025496.

Sherwood, S. G., \& Paredes, M. (2014). Dynamics of perpetuation: The politics of keeping highly toxic pesticides on the market in Ecuador. Nature and Culture, 9(1), 21-44. https://doi.org/10.3167/ nc.2014.090102.

Shove, E. (2003). Comfort, cleanliness and convenience: The social organization of normality. Oxford: Berg.

Shove, E., \& Pantzar, M. (2005). Consumers, producers and practices: Understanding the invention and reinvention of Nordic walking. Journal of Consumer Culture, 5(1), 43-64. https://doi. org/10.1177/1469540505049846.

Shove, E., \& Walker, G. (2010). Governing transitions in the sustainability of everyday life. Research Policy, 39(4), 471-476. https://doi.org/10.1016/j.respol.2010.01.019.

Sieferle, R. P. (2010). The subterranean forest. Energy systems and the industrial revolution. Cambridgeshire: White Horse Press.

Sixt, G. N., Klerkx, L., \& Griffin, T. S. (2018). Transitions in water harvesting practices in Jordan's rainfed agricultural systems: Systemic problems and blocking mechanisms in an emerging technological innovation system. Environmental Science \& Policy, 84, 235-249. https://doi.org/10.1016/j. envsci.2017.08.010.

Slingerland, M., \& Schut, M. (2014). Jatropha developments in mozambique: Analysis of structural conditions influencing niche-regime interactions. Sustainability, 6(11), 7541-7563. https://doi. org/10.3390/su6117541. 
Smith, A. (2006). Green niches in sustainable development: The case of organic food in the United Kingdom. Environment and Planning C: Government and Policy, 24(3), 439-458. https://doi. org/10.1068/c0514j.

Smith, A. (2007). Translating sustainabilities between green niches and socio-technical regimes. Technology Analysis \& Strategic Management, 19(4), 427-450. https://doi.org/10.1080/0953732070 1403334.

Smith, J., \& Jehlička, P. (2007). Stories around food, politics and change in Poland and the Czech Republic. Transactions of the Institute of British Geographers, 32(3), 395-410. https://doi.org/10. 1111/j.1475-5661.2007.00258.x.

Smith, A., Stirling, A., \& Berkhout, F. (2005). The governance of sustainable socio-technical transitions. Research Policy, 34(10), 1491-1510. https://doi.org/10.1016/j.respol.2005.07.005.

Smith, A., Voß, J.-P., \& Grin, J. (2010). Innovation studies and sustainability transitions: The allure of the multi-level perspective and its challenges. Research Policy, 39(4), 435-448. https://doi. org/10.1016/j.respol.2010.01.023.

Southerton, D., Chappells, H., \& van Vliet, B. (2004). Sustainable consumption: The implications of changing infrastructures of provision. Cheltenham: Edward Elgar Publishing.

Sovacool, B. K., \& Hess, D. J. (2017). Ordering theories: Typologies and conceptual frameworks for sociotechnical change. Social Studies of Science, 47(5), 703-750. https://doi.org/10.1177/03063 12717709363.

Spaargaren, G., \& van Vliet, B. (2000). Lifestyles, consumption and the environment: The ecological modernization of domestic consumption. Environmental Politics, 9(1), 50-76. https://doi. org/10.1080/09644010008414512.

Stahlbrand, L. (2016). The food for life catering mark: Implementing the sustainability transition in university food procurement. Agriculture, 6(3), 46. https://doi.org/10.3390/agriculture6030046.

STRN. (2017). A research agenda for the sustainability transitions research network, https://transition snetwork.org/wp-content/uploads/2018/01/STRN_Research_Agenda_2017.pdf. Accessed 19 May 2018.

Sustainability Transitions Research Network. (2010). A mission statement and research agenda for the sustainability transitions research network, www.transitionsnetwork.org/files/STRN_research_ agenda_20_August_2010(2).pdf. Accessed 14 May 2017.

Sustainability Transitions Research Network. (2018). Newsletter 27: March 2018, https://transitionsnetw ork.org/wp-content/uploads/2018/04/27th-STRN-newsletter-.pdf. Accessed April 20, 2018.

Sutherland, L.-A., Peter, S., \& Zagata, L. (2015). Conceptualising multi-regime interactions: The role of the agriculture sector in renewable energy transitions. Research Policy, 44(8), 1543-1554. https:// doi.org/10.1016/j.respol.2015.05.013.

Truffer, B., \& Markard, J. (2017). Transition studies: A Ph.D. guide into the wild. In 2nd Ph.Ds. in Transitions Conference. Lausanne, https://www.ethz.ch/content/dam/ethz/.../sustainability.../Truff er_Markard_2017.pdf. Accessed 18 April 2018.

Turner, J. A., Williams, T., Nicholas, G., Foote, J., Rijswijk, K., Barnard, T., et al. (2017). Triggering system innovation in agricultural innovation systems: Initial insights from a community for change in New Zealand. Outlook on Agriculture, 46(2), 125-130. https://doi.org/10.1177/00307 27017708500 .

Twine, R. (2015). Understanding snacking through a practice theory lens. Sociology of Health \& Illness, 37(8), 1270-1284. https://doi.org/10.1111/1467-9566.12310.

Twomey, P., \& Gaziulusoy, A. I. (2014). Review of system innovation and transitions theories-Concepts and frameworks for understanding and enabling transitions to a low carbon built environment. Working paper for the Visions \& Pathways project, March 2014, http://www.visionsand pathways.com/wp-content/uploads/2014/06/Twomey_Gaziulusoy_Innovation-and-Transition -Theory.pdf. Accessed 12 Oct 2017.

Tyfield, D., Ely, A., \& Geall, S. (2015). Low carbon innovation in China: From overlooked opportunities and challenges to transitions in power relations and practices. Sustainable Development, 23(4), 206-216. https://doi.org/10.1002/sd.1588.

UNEP. (2011). Towards a green economy: Pathways to sustainable development and poverty eradication, http://www.greengrowthknowledge.org/sites/default/files/downloads/resource/Green_Econo my_Report_UNEP.pdf. Accessed 14 May 2017.

Van den Bergh, J., \& Oosterhuis, F. (2008). An evolutionary-economic analysis of energy transitions. In J. C. J. M. van den Bergh \& F. R. Bruinsma (Eds.), Managing the transition to renewable energy. Theory and practice from local, regional and macro perspectives. Cheltenham: Edward Elgar. 
van den Heiligenberg, H. A. R. M., Heimeriks, G. J., Hekkert, M. P., \& van Oort, F. G. (2017). A habitat for sustainability experiments: Success factors for innovations in their local and regional contexts. Journal of Cleaner Production, 169, 204-215. https://doi.org/10.1016/j.jclepro.2017.06.177.

van Gameren, V., Ruwet, C., \& Bauler, T. (2015). Towards a governance of sustainable consumption transitions: How institutional factors influence emerging local food systems in Belgium. Local Environment, 20(8), 874-891. https://doi.org/10.1080/13549839.2013.872090.

van Mierlo, B., Janssen, A., Leenstra, F., \& van Weeghel, E. (2013). Encouraging system learning in two poultry subsectors. Agricultural Systems, 115, 29-40. https://doi.org/10.1016/j.agsy.2012.10.002.

Vankeerberghen, A., \& Stassart, P. M. (2016). The transition to conservation agriculture: An insularization process towards sustainability. International Journal of Agricultural Sustainability, 14(4), 392-407. https://doi.org/10.1080/14735903.2016.1141561.

Vinnari, M., \& Vinnari, E. (2014). A framework for sustainability transition: The case of plant-based diets. Journal of Agricultural and Environmental Ethics, 27(3), 369-396. https://doi.org/10.1007/s1080 6-013-9468-5.

Vitters $\emptyset$, G., \& Tangeland, T. (2015). The role of consumers in transitions towards sustainable food consumption. The case of organic food in Norway. Journal of Cleaner Production, 92, 91-99. https://doi. org/10.1016/j.jclepro.2014.12.055.

Vivero-Pol, J. (2017). Food as commons or commodity? Exploring the links between normative valuations and agency in food transition. Sustainability, 9(3), 442. https://doi.org/10.3390/su9030442.

Vlahos, G., Karanikolas, P., \& Koutsouris, A. (2017). Integrated farming in Greece: A transition-to-sustainability perspective. International Journal of Agricultural Resources, Governance and Ecology, 13(1), 43. https://doi.org/10.1504/ijarge.2017.084033.

Wals, A. E. J. (2007). Social learning towards a sustainable world: Principles, perspectives, and praxis. Wageningen: Wageningen Academic Publishers.

Warde, A. (2005). Consumption and theories of practice. Journal of Consumer Culture, 5(2), 131-153. https://doi.org/10.1177/1469540505053090.

Weber, K. M., \& Truffer, B. (2017). Moving innovation systems research to the next level: Towards an integrative agenda. Oxford Review of Economic Policy, 33(1), 101-121. https://doi.org/10.1093/oxrep $\operatorname{lgrx} 002$.

Wilson, G. A. (2008). From "weak" to "strong" multifunctionality: Conceptualising farm-level multifunctional transitional pathways. Journal of Rural Studies, 24(3), 367-383. https://doi.org/10.1016/j.jrurs tud.2007.12.010.

Wiskerke, J. S. C. (2003). On promising niches and constraining sociotechnical regimes: The case of Dutch wheat and bread. Environment and Planning A, 35(3), 429-448. https://doi.org/10.1068/a3512.

Wonneck, L. A., \& Hobson, K. (2017). Practice-based spillover effects: Evidence from Calgary's municipal food and yard waste recycling pilot. The Canadian Geographer/Le Géographe canadien, 61(3), 415-427. https://doi.org/10.1111/cag.12391.

WWW-UK. (2013). A 2020 vision for the global food system. Report Summary, http://assets.wwf.org.uk/ downloads/2020vision_food_report_summary_feb2013.pdf. Accessed 16 May 2017.

Zwartkruis, J., Moors, E., Farla, J., \& van Lente, H. (2012). Agri-food in search of sustainability: Cognitive, interactional and material framing. Journal on Chain and Network Science, 12(2), 99-110. https:// doi.org/10.3920/jens2012.x006. 